\title{
Endoplasmic Reticulum Stress Provocation by Different Nanoparticles: An Innovative Approach to Manage the Cancer and Other Common Diseases
}

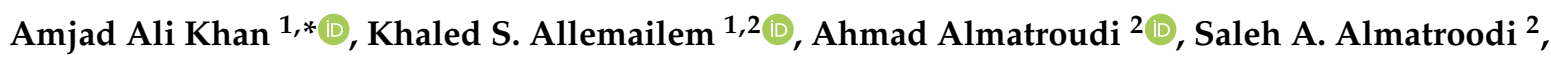 \\ Ali Mahzari ${ }^{3}$, Mohammed A. Alsahli ${ }^{2}$ and Arshad Husain Rahmani ${ }^{2}$ \\ 1 Department of Basic Health Sciences, College of Applied Medical Sciences, Qassim University, \\ Buraydah 52571, Saudi Arabia; k.allemailem@qu.edu.sa \\ 2 Department of Medical Laboratories, College of Applied Medical Sciences, Qassim University, \\ Buraydah 52571, Saudi Arabia; aamtrody@qu.edu.sa (A.A.); smtrody@qu.edu.sa (S.A.A.); \\ shly@qu.edu.sa (M.A.A.); ah.rahmani@qu.edu.sa (A.H.R.) \\ 3 Department of Laboratory Medicine, Faculty of Applied Medical Sciences, Albaha University, \\ Albaha 65527, Saudi Arabia; amoosa@bu.edu.sa \\ * Correspondence: akhan@qu.edu.sa
}

Academic Editor: Kogularamanan Suntharalingam

Received: 14 October 2020; Accepted: 14 November 2020; Published: 16 November 2020

\begin{abstract}
A proper execution of basic cellular functions requires well-controlled homeostasis including correct protein folding. Endoplasmic reticulum (ER) implements such functions by protein reshaping and post-translational modifications. Different insults imposed on cells could lead to ER stress-mediated signaling pathways, collectively called the unfolded protein response (UPR). ER stress is also closely linked with oxidative stress, which is a common feature of diseases such as stroke, neurodegeneration, inflammation, metabolic diseases, and cancer. The level of ER stress is higher in cancer cells, indicating that such cells are already struggling to survive. Prolonged ER stress in cancer cells is like an Achilles' heel, if aggravated by different agents including nanoparticles (NPs) may be exhausted off the pro-survival features and can be easily subjected to proapoptotic mode. Different types of NPs including silver, gold, silica, graphene, etc. have been used to augment the cytotoxicity by promoting ER stress-mediated cell death. The diverse physico-chemical properties of NPs play a great role in their biomedical applications. Some special NPs have been effectively used to address different types of cancers as these particles can be used as both toxicological or therapeutic agents. Several types of NPs, and anticancer drug nano-formulations have been engineered to target tumor cells to enhance their ER stress to promote their death. Therefore, mitigating ER stress in cancer cells in favor of cell death by ER-specific NPs is extremely important in future therapeutics and understanding the underlying mechanism of how cancer cells can respond to NP induced ER stress is a good choice for the development of novel therapeutics. Thus, in depth focus on NP-mediated ER stress will be helpful to boost up developing novel pro-drug candidates for triggering pro-death pathways in different cancers.
\end{abstract}

Keywords: endoplasmic reticulum stress; nanoparticles; ER stress mediated diseases; drug nanoformulation; anticancer drugs

\section{Introduction}

The endoplasmic reticulum (ER) comprises a vast membranous network within a eukaryotic cell, which performs different functions such as protein folding and processing, lipid biosynthesis, and calcium storage, etc. This organelle acts as the major assembly point for almost all the secretory 
and integral membrane proteins. Within the ER, the nascent polypeptides enter through translocation and are properly folded by different covalent and non-covalent modifications and are then assembled to achieve their higher order complexities [1,2]. The presence of different chaperons within the ER lumen like heat shock protein homologues (hsp-40, -70, -90), ER lectins (calreticulin, calnexin) and thiol oxidoreductases such as protein disulfide isomerase (PDI), serpins, binding immunoglobulin protein (BiP), etc. makes this organelle a unique and ideal system for proper protein folding [3]. Different types of co-translational and post-translational modifications occur inside the polypeptide chains within the ER lumen and are shaped as native 3-dimensional proteins. These final form proteins are transported across the ER for their further final destinations. In addition, this organelle also performs its role in checking any improperly folded proteins, which are selectively identified and marked for destruction. In this way, only the properly folded proteins, which pass the checkpoint of ER quality control, are allowed to exit. In addition to protein modifications, the ER is responsible of other multiple functions as vesicular traffic, biosynthesis of cholesterol, phospholipids, and calcium buffering [4].

The quality control system of ER, responsible for the proper shaping of proteins, is prone to influence by different intracellular as well as extracellular stimuli. Different factors affect this proper protein folding capacity, which includes oxidative stress, hypoxia, viral infection, aberrant $\mathrm{Ca}^{2+}$ regulation, glucose deprivation, environmental toxins, mutant protein expression, hypoglycemia, and aging, etc. [5]. In addition, ER stress is induced by several other factors like high sugar and high fat diet, and some drugs as bortezomib, viracept, celebrex, celecoxib, etc. Furthermore, several natural compounds (e.g., tunicamycin, thapsigargin, and geldanamycin) also induce this stress. To buffer the ER stress, a cell can use four different strategies like translational attenuation, UPR upregulation, ER compartmental proliferation, or finally programmed cell execution [6,7].

The redox-state of ER is closely linked with its protein-folding homeostasis. Any alteration of this redox-balance has a very high impact on disulfide bond formation within the ER lumen, where both the oxidizing and reducing reagents disrupt the protein folding, creating the ER stress [8]. At the time of oxidative protein folding, the thiol groups present on cysteines are oxidized and lead to the formation of disulfide bonds with the generation of hydrogen peroxide $\left(\mathrm{H}_{2} \mathrm{O}_{2}\right)$. During the ER stress, this disulfide bond formation dysregulation results in greater reactive oxygen species (ROS) accumulation, resulting in oxidative stress (OS) (Figure 1). Furthermore, some UPR components like the C/EBP homologous protein $(\mathrm{CHOP})$ can also contribute to this OS. The ER stress also results in mitochondrial dysfunctions, causing increased mitochondrial ROS formation. It has also been reported in many in vivo and in vitro models that the ER stress and OS emphasize each other positively in a feed-forward loop, leading to the interference of cellular functions and activating pro-apoptotic signaling [9].

Any type of disturbance, which hinders the normal functioning of the ER, results in upregulation of unfolded protein response (UPR), which initially aims to compensate for the damage. However, in some severe situations that shatter the ER function severely or for a prolonged time, the UPR signal triggers the cell death. This mechanism of ER stress to cell death remains enigmatic, as multiple participants have been described with clear transparency. Several common disease like diabetes, cardiac problems, ischemia, neurodegeneration, and cancer, etc. have been linked to ER stress mediated cell death [10].

In this review, we mainly aimed to focus on an overview of ER stress, its intervened diseases, the role of the physico-chemical properties of different NPs on biological systems as toxicological and therapeutic agents, and their role to induce ER stress. Almost no review article has been published thus far, which includes different metal and non-metal based NPs and their specific roles as ER stress inducing agents. This review may definitely provide a significant information about diverse NP mediated ER stress as an innovative approach for the management of disease therapy including cancer. 


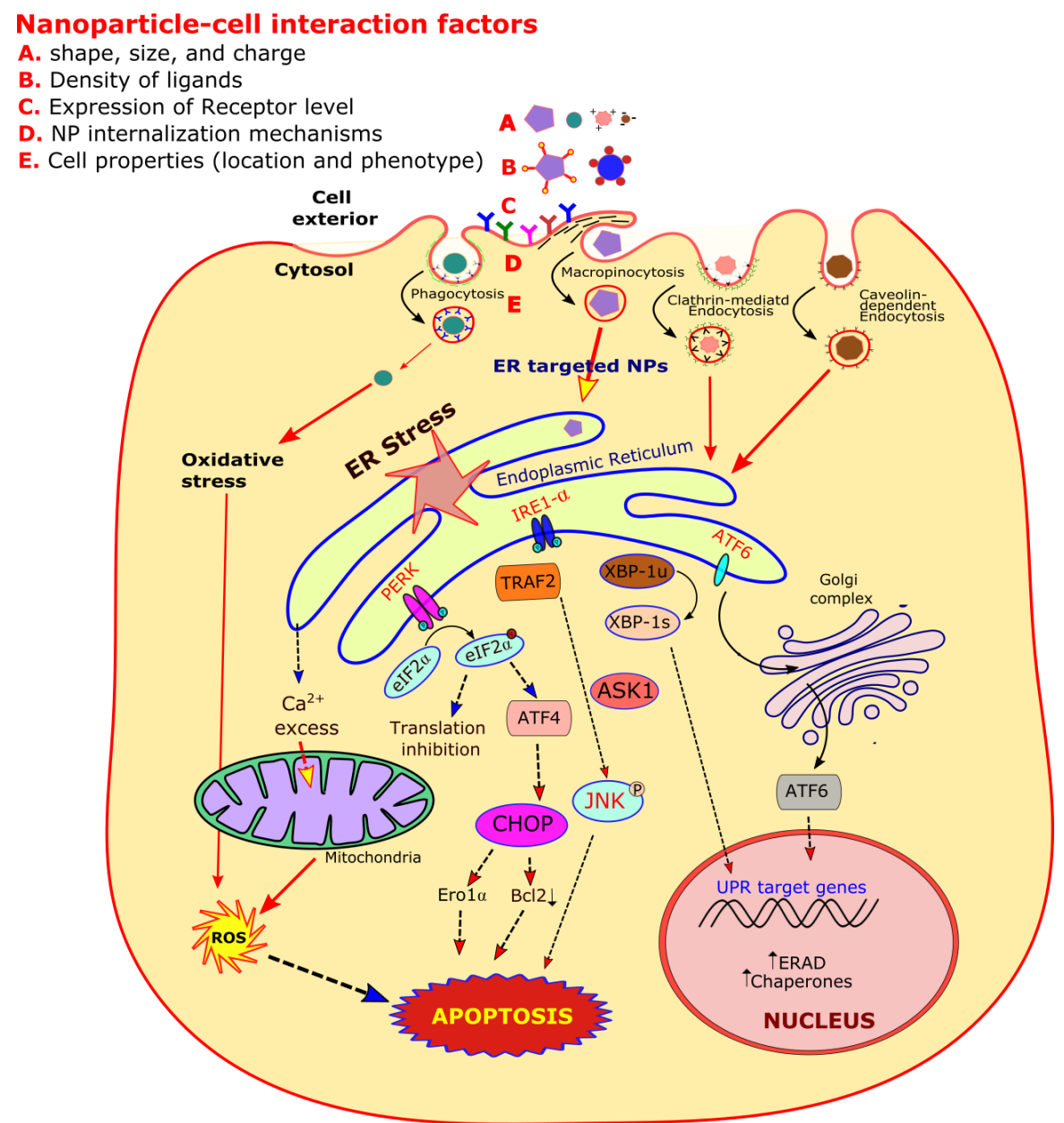

Figure 1. A diagrammatic representation of endoplasmic reticulum (ER) stress and oxidative stress facilitated signaling pathways induced by different types of nanoparticles (NPs). The NP-cell interaction depends on their shape, size, charge, and ligand density. This interaction also depends on cell membrane receptor types, internalization mechanisms, and other cell properties.

\section{An Overview of Endoplasmic Reticulum (ER) Stress}

Different factors that affect the normal activity of ER like protein disulfide bond formation and glycosylation are affected by overexpressed mutated proteins, which results in its stress. To respond to ER stress properly, the eukaryotic cells have adapted a group of signal transduction pathways, which are collectively termed as unfolded protein response (UPR). UPR is a homeostatic signal transduction network that coordinates the retrieval of ER functions. A cell undergoes apoptosis, if there is any failure that results in the adaptation of ER stress. Insight knowledge has led to the recognition of regulatory mechanisms and crosstalk signaling, which involves three branches of UPR. These three branches are initiated by inositol-requiring protein $1 \alpha$ (IRE1 $\alpha)$, protein kinase RNA-like ER kinase (PERK), and activating transcription factor 6 (ATF6) (Figure 1). The relationship between UPR and the cellular decision about life or death during the ER stress is fascinating and has led to special interests to find the link between UPR signaling and different human diseases including cancer. Here in this section of the review, we focus in brief on the molecular mechanism of UPR signaling that leads to cell death during ER stress [11].

The most phylogenetically preserved UPR signaling occurs through IRE1 $\alpha$. The IRE1 $\alpha$ gets oligomerized in response to the ER stress and activates the kinase and endoribonuclease functions, which are present on its cytosolic domain $[12,13]$. The cytoprotective output of IRE1 $\alpha$ is mediated by the specific splicing of Xbp1 mRNA. The spliced Xbp1 encrypts a strong transcription factor, whose gene 
targets code the proteins, which enhance the protein folding capacity of ER and the degradation of misfolded proteins. This signal transduction pathway protects the cell by reducing the stimulus that ultimately leads to ER stress [14,15].

As an additional function to ER stress, the IREI $\alpha$ can promote cell death through the activation of c-Jun N-terminal kinase (JNK). The IRE1 $\alpha$ kinase domain binds with the adapter molecule TRAF2, which leads to the activation of apoptosis signal regulating kinase (ASK1) that phosphorylates and activates JNK. The activation of JNK triggers the cell death in response to UV irradiation or TNF $\alpha$ receptor activation [16,17].

The cell death is also promoted by IRE1 $\alpha$ signaling through the activation of caspases, which act as the actual apoptosis effectors. The tumor necrosis factor-receptor associated factor 2 (TRAF2), an adapter molecule that interacts with procaspase-12, and this interface gets disrupted by the ER stress, which promotes the conversion of procaspase-12 to the active enzymes [18] (Figure 1).

The signal transduction of UPR mediated ER stress, through the PERK, also provokes the proapoptotic effects after its activation. The PERK protein also bears an ER-lumenal peptide domain that is homologous as IRE1 $\alpha$. This domain monitors the proper protein folding within the ER lumen. The ER stress also leads to the PERK oligomerization like that of IRE1 $\alpha$, and this leads to the activation of kinase activity present in its cytosolic domain [19]. Eukaryotic initiation factor $2 \alpha$ (eIF2 $\alpha$ ) is the target for this kinase activity, which is a ubiquitous cofactor. This cofactor is needed for the assembly of $80 \mathrm{~S}$ ribosomal subunits to inaugurate the protein synthesis [20]. The PERK mediated phosphorylation of eIF $2 \alpha$ inhibits its functions and leads to the decline of protein synthesis as the ribosomal subunits do not assemble efficiently on mRNAs [21,22]. In this way, PERK signaling shields a cell from ER stress-mediated protein misfolding. This signaling of translational attenuation mediates a good protective advantage to the cells under stress. This signaling may also lead to cell death, if the protein synthesis drops below the level necessary to sustain vital activities.

To control the translational over-attenuation, the PERK signaling also leads to the activation of a regulatory protein phosphatase subunit GADD34. This promotes the dephosphorylation of eIF2 $\alpha$, which helps to restore the mRNA-ribosomal assembly [23]. However, these signal transduction mechanisms are still unclear as to whether the translational attenuation damages or protects a cell.

The third brand of UPR signal transduction during an ER stress is initiated by ATF- $6 \alpha$, which is a transmembrane stress sensor protein [24,25]. In contrast to PERK and IRE1 $\alpha$, which are ubiquitous, this type of ER stress transducer is expressed in a cell and tissue specific manner [26]. This ER transmembrane protein also possesses a stress-sensing ER luminal domain that is coupled through the transmembrane segment to the cytosolic transcription factor domain [27]. With the initiation of ER stress, the ATF- $6 \alpha$ operates from the ER to the Golgi complex. In the Golgi complex, some specific proteases break the ATF- $6 \alpha$ transmembrane domain and release the cytosolic domain [28]. This detached protein fragment translocates to the nucleus, where it acts as a transcription factor. This phenomenon upregulates the UPR target genes, which are overlapped with the genes activated by ATF- 4 and XBP-1. This way, ATF- $6 \alpha$ is believed to protect a cell from stress [29]. However, some findings also suggest that ATF- $6 \alpha$ possesses some proapoptotic functions [30].

As the ER stress regulates the UPR, it can lead to cell death. It is not astonishing that such circumstances can also promote the protein misfolding or declined cellular abilities. To handle such misfolded proteins, the stress ultimately results in different cellular dysfunctions and diseases including cancer. Therefore, any inappropriate UPR activation may be harmful to a cell, leading to cell death. Next, we discuss in detail how this artificially induced ER-stress strategy can be a better therapeutic opportunity to cure an organism from different diseases including cancer.

\section{Endoplasmic Reticulum Stress Mediated Diseases}

Any type of perturbation within a cell that affects the normal functioning of the ER activates special signaling cascades that organize the adaptive and apoptotic responses. It is now well evidenced that prolonged ER stress leads to the development and progression of different diseases which include liver 
diseases, atherosclerosis, neurodegeneration, type 2 diabetes, and cancer, etc. A proper understanding of the molecular mechanisms of this ER stress response can be a potential strategy to treat such diverse diseases [31]. The ER stress mediated UPR contributes to different types of diseases including cancer, as listed in Table 1.

Table 1. Some common types of diseases induced by endoplasmic reticulum stress.

\begin{tabular}{|c|c|c|c|}
\hline S. No. & Disease & Role of ER Stress & References \\
\hline 1. & Type 2 diabetes & $\begin{array}{l}\text { ER stress is induced by obesity, gluconeogenesis gets affected by } \\
\text { ATF6. The pancreatic } \beta \text {-cell death is induced by hyperglycemia and } \\
\text { free fatty acids through CHOP signal }\end{array}$ & [32] \\
\hline 2. & $\begin{array}{l}\text { Parkinson's } \\
\text { disease }\end{array}$ & Substrate of Parkinson accumulation in ER, leads to ER stress & [33] \\
\hline 3. & $\begin{array}{l}\text { Alzheimer's } \\
\text { disease }\end{array}$ & The $\mathrm{CHOP}$ cascade gets activated by mutant presenilin & [34] \\
\hline 4. & Atherosclerosis & $\begin{array}{c}\text { Smooth muscle and endothelial cell death is mediated by } \\
\text { hyperhomocysteinemia, oxidized phospholipids and cholesterol } \\
\text { loading which leads to CHOP cascade. } \\
\text { Macrophage death is induced by CHOP cascade which is generated } \\
\text { by atherosclerosis related stimuli }\end{array}$ & [35] \\
\hline 5. & $\begin{array}{l}\text { Alcoholic liver } \\
\text { disease }\end{array}$ & The induction of GRP78 and CHOP occurs by alcohol consumption & [36] \\
\hline 6. & $\begin{array}{l}\text { Non-alcoholic } \\
\text { fatty liver disease }\end{array}$ & SREBP-1c is induced by ER stress & [37] \\
\hline 7. & $\begin{array}{l}\mathrm{HBV} \text { and } \mathrm{HCV} \\
\text { infection }\end{array}$ & $\begin{array}{c}\text { GRP78 and GRP } 94 \text { are induced by HBV, while IRE1-XBP1 pathway is } \\
\text { suppressed by HCV }\end{array}$ & [38] \\
\hline 8. & $\begin{array}{l}\text { Amyotrophic } \\
\text { lateral sclerosis }\end{array}$ & ER stress is activated by mutant SOD1 aggregates & [39] \\
\hline 9. & Cancer & Different cancers lead to the induction of GRP78 and XBP1 & [40] \\
\hline 10. & Ovarian cancer & The ovarian cancer patients have increased expression of GRP78 & [41] \\
\hline 11. & Liver cancer & $\begin{array}{l}\text { In human hepatocellular carcinoma tissues and human } \\
\text { hepatocellular carcinoma cells (SMMC7721), the enhanced expression } \\
\text { of Grp78 promotes the invasion of hepatocellular carcinoma both } \\
\text { in vivo and in vitro }\end{array}$ & [42] \\
\hline 12. & Prostate cancer & $\begin{array}{l}\text { The hormone-resistant prostate cancer cells promote } \\
\text { the enhanced expression of Grp78 to the cell surface, which can be } \\
\text { further elevated by ER stress in human prostate adenocarcinoma } \\
\text { hormone-resistant cells, C4-2B }\end{array}$ & [43] \\
\hline 13. & Lymphoma & $\begin{array}{l}\text { The splicing of XBP1 stimulates tumor growth during } \\
\text { hypoxic conditions in such patients }\end{array}$ & [44] \\
\hline \multirow{4}{*}{14.} & \multirow{4}{*}{ Breast cancer } & $\begin{array}{c}\text { In human breast cancer tissue and breast carcinoma cell lines } \\
\text { (MDA-MB-231, MCF-7, HCC1500 HS578T), and cells show elevated } \\
\text { levels of mRNA and protein Bip/Grp78 }\end{array}$ & [45] \\
\hline & & During hypoxia, increased level of ATF4 occurs in MCF7 cell lines & [46] \\
\hline & & $\begin{array}{l}\text { Increased expression of unspliced XBP1 mRNA favoring apoptosis of } \\
\text { cancer cells and higher levels of spliced XBP1 mRNA increasing } \\
\text { cancer survival in human breast cancer tissue }\end{array}$ & [47] \\
\hline & & $\begin{array}{l}\text { The Hormone-resistant breast cancer cells stimulate Grp78 expression } \\
\text { on the cell surface, which is further elevated by ER stress in human } \\
\text { breast cancer hormone-resistant cells and MCF-7/BUS-10 cell lines }\end{array}$ & [43] \\
\hline \multirow[b]{2}{*}{15.} & \multirow[b]{2}{*}{ Colorectal cancer } & $\begin{array}{c}\text { Increased expression of ATF4 occurs during severe hypoxia in HT29 } \\
\text { cells }\end{array}$ & [48] \\
\hline & & $\begin{array}{c}\text { Increased expression of Grp78 on CRC cell surfaces, which promotes } \\
\text { CRC cell migration and invasion } \\
\text { In human colon carcinoma (SW480, HT29, DLD1, SW620, and Lovo) } \\
\text { cell lines }\end{array}$ & [49] \\
\hline
\end{tabular}


Table 1. Cont.

\begin{tabular}{|c|c|c|c|}
\hline S. No. & Disease & Role of ER Stress & References \\
\hline \multirow{3}{*}{16.} & \multirow{3}{*}{$\begin{array}{l}\text { Brain and central } \\
\text { nervous } \\
\text { system tumor }\end{array}$} & $\begin{array}{l}\text { Enhanced expression of Grp78 is observed in human brain tumor } \\
\text { specimens and glioma cell lines (U87, A172, U251, LNZ308, LN-229 } \\
\text { and LN-443) }\end{array}$ & [50] \\
\hline & & $\begin{array}{l}\text { The depletion of XBP-1 dramatically sensitizes U373 cells to viral } \\
\text { oncolysis in U373 glioblastoma cells }\end{array}$ & [51] \\
\hline & & $\begin{array}{l}\text { The Inhibition of IRE1 } \alpha \text { enhances the oncolytic therapy in } \\
\text { glioblastoma patient samples }\end{array}$ & [51] \\
\hline 17. & Pancreatic cancer & $\begin{array}{l}\text { The expression of PERK supports the proliferation of beta-cell } \\
\text { insulinoma and promotes angiogenesis in human tumor xenograft } \\
\text { mice }\end{array}$ & [52] \\
\hline
\end{tabular}

\section{Endoplasmic Reticulum Stress and Cancer}

As we know, cancer cells possess a higher growth rate and proliferation, so these cells demand an increased rate of protein folding and assembly within the ER. In addition to this, some tumor cells express additional mutant proteins that are not properly folded, which further leads to ER stress mediated UPR cascades. The initiation of malignancy is followed by poor vascularization, which leads to nutrient starvation around the tumor mass. The increased hypoxia and changes in the redox environment strongly induce the UPR signal transduction cascades. Recent evidence strongly suggests that cancer cells favor the UPR environment and this setting acts as an important survival pathways for such cells. Different types of cancers have been reported with a higher expression of ER chaperons and enhanced appearance of UPR markers. It has also been found that GRP78 expression is increased in hepatocarcinoma, adenocarcinoma, colon, and breast cancer cell lines [53]. The increased expression of GRP78 is believed to favor the cancer cell survival signals and also convenes the drug resistance. The pathologic grade and recurrence of cancer is also correlated with higher expression of GRP78 in patients suffering from liver, breast, prostate, gastric, and colon cancer [54].

In parallel to the GRP78 expression, the overexpression of XBP1 has been reported in different human cancers like hepatocellular carcinoma and breast cancer. In addition, overexpressing XBP1 in transgenic animal models has been reported to achieve plasma cell neoplastic transformation as well as the development of myeloma [55]. Even though many studies support the overexpression of UPR in human cancers and malignant animal models, a recent report showed the downregulation of UPR in prostate cancer mouse models [40]. Therefore, all these observations conclude that ER stress during cancer may be more complicated, as initially predicted.

It is now well documented that the usual drug resistance approach, experienced by the different types of cancer cells, can be overcome by targeting the ER stress signaling pathways. These anticancer drugs are believed to reduce the adaptation of tumor cells for inflammation, hypoxia, and angiogenesis [56]. In this regard, several anti-tumor drugs have recently been designed and studied, which directly act through ER stress pathways and affect cancer progression. However, the proper drug targets (cancer cells only) remain a challenge to the use of such powerful drugs $[57,58]$.

\section{Endoplasmic Reticulum Stress as a Novel Target to Fight against Cancer Cells}

The controlled ER stress experienced by cancer cells employs their antiapoptotic functions, thus supporting cell survival and also enhancing the chemoresistance. Any type of aggravation exceeding the protective capacity of these cancer cells can switch on their proapoptotic module [59]. Therefore, targeting and enhancing the ER stress in cancer cells is emerging as a novel target for different anticancer drugs and metal nanoparticles. To understand the association between aggravated ER stress and apoptosis can be an innovative approach to combat different types of cancer.

The UPR is considered as a novel therapeutic target in different cancer cells, and several pharmacological agents induce impairment to UPR and lead to cell death [60,61]. The different pharmacological agents specified are 17-AAG, Bortezomib, and Brefeldin-A, etc., which have been 
recently used to induce UPR inhibition $[62,63]$. In-clinic chemotherapeutic compounds like cisplatin and doxorubicin have also been used to explore the new targets for inducing the ER stress.

In the recent past, different types of cytotoxic compounds have been engineered to target the ER, which often exhibit selectivity for some cancer cells compared to normal cells. These drugs have been successfully used to induce ER stress beyond the cancer cell capacity to acquire immunogenic cell death. Some of the potential ER stress inducing agents include metal complex NPs possessing redox activity, which appear as promising candidates to fight cancer [11].

Dozens of metal and non-metal based NPs have been engineered in the last two decades that are reported to kill different types of cancer cells through the induction of ER stress. Some of these NPs exhibit anticancer activity even at nanomolar concentrations, used either as in vitro or as in vivo conditions.

\section{Physico-Chemical Characteristics of Nanoparticles (NPs) and Their Role on Biological Systems}

A vast comprehension about the NPs physico-chemical characteristics and its interactions with biological systems is of significant importance. The different physical characteristics of NPs include their composition, shape, size, and surface chemistry, which play a great role in their biomedical applications. These NP fundamental properties play a great role in determining the biological kinetics, biomolecular signaling, transportation, and toxicity in both in vivo and in vitro studies [64].

First of all, a typical NP is synthesized chemically to manage its size and surface chemistry, is loaded with specific drugs and surface coated with some polymers, and is eventually administered into a cell culture or any animal model. Recent studies have indicated that the interaction of NPs with serum proteins and cell membrane receptors is specified by the NP basic design, which determines its cell uptake, organelle interaction, gene expression, and cyto-toxicity. The NPs interact with cell membrane in multiple ways depending upon the cell membrane ultra-structure and the NPs' physico-chemical state [65] (Figure 1).

A NP is also designed to dictate the interaction between the ligands with the receptor targets. A NP can be synthesized by having multiple ligands to offer multivalent effects when it interacts with multiple receptors present on the cell surface. This results in more binding strength (avidity) compared to the sum of individual affinities. The density of ligands and its specific curvature, present on the surface of NPs, also contributes in overall avidity strength. The affinity of a ligand binding increases proportionally with the NP size. This phenomenon has been checked by studying the avidity between Herceptin to ErbB2 receptor as $10^{-10} \mathrm{M}$ in solution, $5.5 \times 10^{-12} \mathrm{M}$ on a $10 \mathrm{~nm}$ diameter NP, and $1.5 \times 10^{-13} \mathrm{M}$ on a $70 \mathrm{~nm}$ NP [66]. However, other factors in addition to binding affinity may also participate in determining the biological effects. This phenomenon occurs when 40-50 nm AuNP induces its strongest downstream signaling via the ErbB2 receptor. In addition, NP design may also induce differential cell signaling compared with the free ligand in solution. This phenomenon is supported when Herceptin coated, $40-50 \mathrm{~nm}$, AuNPs altered the cellular apoptosis by affecting the caspase enzyme activities [66].

Similarly, NPs conjugated with receptor-specific peptides may also improve their capability of angiogenesis induction [67]. The NPs can also lead to some unexpected phenomena in cell signaling. For example, intercellular adhesion molecule I (ICAM-I) coated NPs get internalized, which is an unusual finding because ICAM-1 is not known for triggering endocytosis [68]. A study has shown that carbon-NPs $(14 \mathrm{~nm})$ interact with $\beta 1$-integrins and epidermal growth factor receptors (EGFRs) and induce the activation of Akt signaling, thus leading to cell proliferation [69]. Furthermore, an additional complexity occurs when the NP-ligand complexes, which can also lead to the denaturation of proteins present on the cell surface. This denaturation can lead to altered NP receptor binding, increased nonspecific interactions, or provoked inflammation. This phenomenon is observed when lysozymes are attached to AuNPs, denature, and interact with other lysozyme proteins, producing protein-NP aggregation and finally inflammation [70,71]. 


\section{Nanoparticles Used as Toxicological and Therapeutic Agents Including ER Stress}

The NPs synthesized from different metals and non-metals have proven a great opportunity for cancer theranostics. Engineered NPs including silver, gold, copper, and copper oxide NPs, etc. have been reported to induce cytotoxicity, which triggers detectable toxicological changes through the generation of ROS [72,73]. However, the exact correlations between ROS production and ER stress response had not been clearly outlined in toxic assessment from different nanomaterials. Different researchers have indicated that some NPs can induce apoptosis through the activation of mitochondria-mediated pathways [74,75]. However, AgNPs have been found to induce apoptosis though the modulation of ER stress reactions. In addition to this, some recent findings have reported that some NPs can lead to the induction of ER stress by activating different cellular reactions, which include the initiation of the apoptotic and inflammatory pathways [72]. The AuNPs have some potential medical usage and have been worked out as efficient cellular ER stress elicitors [76]. Zinc oxide $(\mathrm{ZnO})$ is an important engineered nanomaterial that shows some toxicity to some mammalian cells. The $\mathrm{ZnONP}$ dissolution within the cells leads to the release of toxic $\mathrm{Zn}^{2+}$ ions, which are capable of ROS generation [77]. The Ceria nanoparticles (CeNPs) exhibit some antioxidant activity as they reversibly bind oxygen and can switch between $\mathrm{Ce}^{4+}$ (oxidized) and $\mathrm{Ce}^{3+}$ (reduced) forms at the surface of CeNPs [78].

Some of the metal based NPs and engineered liposomes have therapeutic efficacy against many tumors due to their unique ability to kill only specific cancer cells $[79,80]$. Despite a great enthusiasm to use NPs for different biomedical applications, their advancement in clinical studies is comparatively slow because the adverse outcomes of their use during in vivo studies is not fully understood [81]. Therefore, there is an urgent requirement to properly investigate the NP induced toxicity mechanisms within the cells, as this strategy is very eagerly required to combat cancer. In addition, the proper mechanism of different NP action is required to ensure their safe use as well as the new design of more biocompatible NPs. In addition to the multiple use of NPs for commercial purposes, some other metalloid and non-metal NPs like silicon based NPs and carbon nanotubes (CNTs) have proven to have great potential as targeted-delivery drug nanocarriers [82].

Several specific mechanisms have been proposed to explain the toxicological role of NPs. Most of the mechanisms support oxidative stress as an important part of their toxicity. This is because various chemically active NPs induce the production of ROS, leading to oxidative damage [83]. Furthermore, some NPs directly provoke an inflammatory response and disturb immune system [84]. NPs have also been reported to dysfunction lysosomes and induce autophagy [85]. In recent years, a deeper look at the mechanism of action of some NPs has supported their role as inducing ER stress as a promising mechanism of NP induced cellular toxicity [86].

Recently, the nanoscale materials including different types of NPs have been effectively used to address different types of cancers in depth. The various types of NPs including lipidic and polymeric NPs and small molecule based supramolecular self-assemblies have been synthesized to precisely navigate to the ER, promote stress, and check the impairment of the UPR [87]. Graphene oxide (GO) based NPs have also emerged as novel candidates with an outstanding panoply of features [88]. These NPs are effectively biodegradable and biocompatible with unique surface modalities allowing for the stacking of drugs and conjugation of targeting moieties [89].

The synthesis of NPs faces a great challenge with regard to their stability and strength in different media. This challenge multiplies even more when NPs are engineered for use as payloads for different drugs, route of delivery, and as organelle targeting. However, there is an urgent need for effective nanoscale tools for the effective impairment of the adaptive UPR and induction of ER stress mediated apoptosis in cancer cells.

Here, we discuss the toxicological and therapeutic effects of some well-known NPs (Table 2) that have been used to induce ER stress as well in different in vivo and in vitro conditions. 
Table 2. The toxicological and therapeutic effects of different types of nanoparticles.

\begin{tabular}{|c|c|c|}
\hline Nanoparticles & Toxicological Effects & Therapeutic Effects \\
\hline \multirow{5}{*}{ Aluminum oxide } & $\begin{array}{c}\text { These NPs used as 1-10 } \mu \mathrm{M} \text { in HBMVECs, decreased } \\
\text { cell viability, decreased mitochondrial functions, } \\
\text { and increased oxidative stress [90] }\end{array}$ & $\begin{array}{l}\text { These NPs were used to penetrated Candida } \\
\text { cells, which disrupted the morphological and } \\
\text { physiological activity of these cells [91] }\end{array}$ \\
\hline & $\begin{array}{l}\text { These NPs } 50-80 \mathrm{~nm} \text { in diameter, were used in } \\
\text { mammalian cells EZ4U, caused no significant toxic } \\
\text { effect on cell viability [92] }\end{array}$ & $\begin{array}{c}\text { These NPs showed good antibacterial, } \\
\text { activity against clinical isolates of P. aeruginosa } \\
\text { was significant [93] }\end{array}$ \\
\hline & $\begin{array}{l}\text { The NP were used as } 160 \mathrm{~nm} \text { in size in HMSC, } \\
\text { caused decreased cell viability [94] }\end{array}$ & $\begin{array}{c}\text { The NPs were effective against gram-positive } \\
\text { and gram-negative bacteria [95] }\end{array}$ \\
\hline & $\begin{array}{l}\text { The NPs were used to check rat blood cells comet } \\
\text { micronuclei, caused dose-dependent genotoxicity } \\
\text { [96] }\end{array}$ & $\begin{array}{l}\text { The NPs were used as anti-cancer therapy, } \\
\text { cytotoxic agents to induce cell death in } \\
\text { human prostate cancer cells, and for boosting } \\
\text { the efficacy of cancer vaccines [97] }\end{array}$ \\
\hline & $\begin{array}{l}\text { These NPs }(50 \mathrm{~nm} \text { ) were used as } 0-5000 \mu \mathrm{g} / \mathrm{mL} \text { to } \\
\text { induce comet DNA damage [98] }\end{array}$ & $\begin{array}{c}\text { The NPs were used as leishmania vaccine to } \\
\text { induce autophagy in macrophages and as } \\
\text { potent vaccination adjuvant [99] }\end{array}$ \\
\hline \multirow{2}{*}{ Copper oxide } & $\begin{array}{l}\text { These NPs were used in human lung epithelial cells, } \\
\text { caused decreased cell viability, increased LDH } \\
\text { expression and enhanced lipid peroxidation [100] }\end{array}$ & $\begin{array}{l}\text { The NPs were used in MCF-7 breast cancer } \\
\text { cell lines for their cytotoxic effect therapeutics } \\
\text { [101] }\end{array}$ \\
\hline & $\begin{array}{l}\text { These NPs were used as } 0.002-0.2 \mu \mathrm{g} / \mathrm{mL} \text { in lung } \\
\text { cancer cells, lead to decreased cell viability [102] }\end{array}$ & $\begin{array}{c}\text { These NPs caused skin cancer cells A-375 } \\
\text { apoptotic cell death by the activation of } \\
\text { caspase-9 [103] }\end{array}$ \\
\hline \multirow{4}{*}{ Gold } & $\begin{array}{l}\text { The NPs caused enhanced lipid peroxidation, } \\
\text { oxidative damage and upregulation of stress } \\
\text { response genes, and protein expression [104] }\end{array}$ & $\begin{array}{l}\text { The NPs caused the Inhibition of } \\
\text { angiogenesis and acted as promising } \\
\text { candidates for the drug delivery systems and } \\
\text { in cancer therapeutics [105] }\end{array}$ \\
\hline & $\begin{array}{l}\text { These NPs induced a significant toxicity, effectively } \\
\text { entered the cytoplasm and nucleus, leading to the } \\
\text { damage of cellular and nuclear membranes [106] }\end{array}$ & $\begin{array}{l}\text { These NPs were used for the treatment of } \\
\text { rheumatic diseases including juvenile } \\
\text { arthritis, psoriasis, palindromic rheumatism, } \\
\text { and discoid lupus Erythematosus [107] }\end{array}$ \\
\hline & $\begin{array}{c}\text { As 5-nm size, induced the cytotoxicity at } 50 \mathrm{mM} \text {, } \\
\text { whereas no toxicity was observed when used as } \\
\text { 15-nm NPs. This shows the size-dependent toxicity } \\
\text { of NPs [108] }\end{array}$ & $\begin{array}{l}\text { These NPs increased the apoptosis in } \\
\text { B-chronic lymphocytic leukemia (BCLL) } \\
\text { treatment-suffering patients [109] }\end{array}$ \\
\hline & $\begin{array}{l}\text { The chitosan-functionalized AuNPs induced the } \\
\text { cytotoxicity and pro-inflammatory responses. } \\
\text { This indicates the charge-dependent toxicity [110] }\end{array}$ & $\begin{array}{l}\text { The NPs were used as surface coating for } \\
\text { different biomedicine applications such as } \\
\text { dressing fabrics, implants, glass surfaces [111] }\end{array}$ \\
\hline \multirow{2}{*}{ Silica } & $\begin{array}{l}\text { These NPs used as } 10-100 \mu \mathrm{g} / \mathrm{mL} \text { in human } \\
\text { bronchoalveolar carcinoma cells showed enhanced } \\
\text { ROS production, increased LDH expression and } \\
\text { higher malondialdehyde formation [112] }\end{array}$ & $\begin{array}{l}\text { As silica-gold nanoshells and gold nanorods } \\
\text { were used for tissue stimulating phantoms } \\
\text { during photothermal therapy [113] }\end{array}$ \\
\hline & $\begin{array}{c}\text { These NPs were used in hepatocellular carcinoma } \\
\text { cells (HepG2), showed enhanced ROS production } \\
\text { and mitochondrial damage due to increased } \\
\text { oxidative stress [114] }\end{array}$ & $\begin{array}{l}\text { The Silica-gold nanoshells were used in } \\
\text { human breast carcinoma cells (in vitro) and } \\
\text { transmissible venereal tumor (in vivo) as a } \\
\text { photothermal therapy agents [115] }\end{array}$ \\
\hline \multirow{3}{*}{ Silver } & $\begin{array}{l}\text { These NPs were used in BRL 3A cell lines and } \\
\text { resulted in decreased cell viability, increased LDH } \\
\text { expression due to enhanced ROS production [116] }\end{array}$ & $\begin{array}{l}\text { These NPs capped with } \\
\text { polyvinyl-pyrrolidone encapsulated in } \\
\text { polymer Nanoparticles Human Glioblastoma. } \\
\text { Astrocytoma epithelial-like Cell line (U87MG) } \\
\text { (in vitro); Swiss mice and severe combined } \\
\text { immunodeficiency mice bearing U87MG } \\
\text { tumors (in vivo) Therapeutic Evaluation [117] }\end{array}$ \\
\hline & $\begin{array}{l}\text { These NPs were used as } 0-20 \mu \mathrm{g} / \mathrm{mL} \text { in human } \\
\text { alveolar cell lines, resulted in decreased cell viability } \\
\text { due to increased ROS production [118] }\end{array}$ & $\begin{array}{c}\text { The silver nano-shell with a carbon core were } \\
\text { used in prostate adenocarcinoma cell line } \\
\text { model as photothermal ablation or radiation } \\
\text { enhanced therapy [119] }\end{array}$ \\
\hline & $\begin{array}{c}\text { These NPs }(20-40 \mathrm{~nm}) \text { in size were used in human } \\
\text { leukemia cell line WST-1 and resulted in decreased } \\
\text { cell viability and the increased expression of LDH } \\
\text { [120] }\end{array}$ & $\begin{array}{l}\text { These NPs acted as the excellent candidates } \\
\text { for bioimaging and act as good anticancer } \\
\text { agents [121] }\end{array}$ \\
\hline
\end{tabular}


Table 2. Cont.

\begin{tabular}{|c|c|c|}
\hline Nanoparticles & Toxicological Effects & Therapeutic Effects \\
\hline \multirow{4}{*}{ Zinc oxide } & $\begin{array}{c}\text { These NPs were used in human colon carcinoma } \\
\text { cells, resulted in increased oxidative stress, decreased } \\
\text { cell viability and the expression of more } \\
\text { inflammatory biomarkers [122] }\end{array}$ & $\begin{array}{l}\text { These NPs when used in murine cell lines } \\
\text { showed cytotoxic effects [123] }\end{array}$ \\
\hline & $\begin{array}{l}\text { Larger NPs }(307-419 \mathrm{~nm}) \text { in size were used in in } \\
\text { human cervix carcinoma cell line }(\mathrm{HEp}-2) \text {, enhanced } \\
\text { the DNA damage and decreased the cell viability } \\
\text { [124] }\end{array}$ & $\begin{array}{l}\text { These NPs were regarded as a possible } \\
\text { treatment for cancer and autoimmune } \\
\text { diseases and were found to be involved in } \\
\text { specific killing of cancer cells and lead to the } \\
\text { activation of human T cells [125] }\end{array}$ \\
\hline & $\begin{array}{c}\text { These NPs resulted in decreased cell viability due to } \\
\text { increased DNA damage and increased ROS } \\
\text { production and leading to apoptosis [126] }\end{array}$ & $\begin{array}{l}\text { These NPs were used in bioimaging, drug } \\
\text { delivery, gene delivery, and as zinc-based } \\
\text { biosensors [127] }\end{array}$ \\
\hline & $\begin{array}{c}\text { These NPs }(<20 \mathrm{~nm}) \text { were used as } 100 \mu \mathrm{g} / \mathrm{mL} \text { in } \\
\text { human bronchial epithelial cells showed decreased } \\
\text { cell viability, LDH release due to enhanced oxidative } \\
\text { stress [130] }\end{array}$ & $\begin{array}{l}\text { These NPs were used to prevents the } \\
\text { helminth infection as it disrupts the electron } \\
\text { transport system and inhibiting the ATP } \\
\text { production, so stopping the contractile } \\
\text { movement of the parasite [131] }\end{array}$ \\
\hline Iron oxide & $\begin{array}{l}\text { These NPs were used in murine macrophage cells } \\
\text { and resulted in decreased cell viability [132] }\end{array}$ & $\begin{array}{l}\text { These NPs as superparamagnetic NPs were } \\
\text { coated with silica-gold nanoshells and used in } \\
\text { head and neck cancer cell lines and resulted } \\
\text { in overexpression of EGFR and were used for } \\
\text { photothermal therapy [133] }\end{array}$ \\
\hline \multirow[b]{2}{*}{ Titanium oxide } & $\begin{array}{l}\text { These NPs were used in mouse models, resulted in } \\
\text { enhanced DNA damage and resulted in genotoxicity } \\
\text { [140] }\end{array}$ & $\begin{array}{l}\text { These NPs were used in CT26 and LL2 mouse } \\
\text { cancer to increase oxidative stress [141] }\end{array}$ \\
\hline & $\begin{array}{c}\text { These NPs were used as } 10-50 \mu \mathrm{g} / \mathrm{mL} \text { in human lung } \\
\text { cells resulted in enhanced oxidative stress, more } \\
\text { DNA adduct formation and increased cytotoxicity } \\
\text { [142] }\end{array}$ & $\begin{array}{l}\text { These NPs were used as efficient drug } \\
\text { delivery systems and in photodynamic } \\
\text { therapy of tumors [143] }\end{array}$ \\
\hline
\end{tabular}

\subsection{Silver Nanoparticles}

Different types of nanomaterials including silver nanoparticles (AgNPs) have been widely used to induce intracellular oxidative stress or ROS-mediated cytotoxicity. The treatment of cells with AgNPs also leads to membrane leakage, poor mitochondrial functions, and declined viability in different cell types like rat hepatocytes, germline stem, and neuroendocrine cells [144,145].

As AgNP induced cytotoxicity is related to oxidative stress, it is strongly evidenced that ER may perform an important role in AgNP mediated apoptosis. The key participants of ER stress include PERK, IRE1, and ATF6 [29]. ATF6 and the spliced form of XBP1 play a positive role in regulating the expression of different ER stress genes that include ER resident chaperons like GRP78/Bip and GRP94 [29,146]. The proapoptotic transcription factor CHOP/GADD153, which acts as a transcription suppressor of Bcl-2, can be induced by the joint ATF6 and PERK/ATF4 pathways $[147,148]$. The overexpression of CHOP induces cell death, while CHOP gene deletion results in cell death attenuation induced by ER stress [149]. Flow cytometry side scatter (FCM-SS) analysis has been previously used to determine the incorporation of AgNP within the cell cytosol. In addition, it has been found that AgNPs induce $\mathrm{Ca}^{2+}$ 
overloading within mitochondria, which indicates that $\mathrm{Ca}^{2+}$ homeostasis plays an important role in AgNP-induced apoptosis (Figure 1).

The dosage of different NP formulations is important in evaluating various adverse effects including ER stress. In mice, the cytotoxicity and genotoxicity have been evaluated at a single dosage of $25 \mathrm{mg} / \mathrm{kg} /$ day for three successive days with 15-100 nm AgNPs [150]. A study showed that AgNPs induce apoptosis via ER stress in cell models [151] as well as in the spleen and liver. Stress marker proteins like BiP and HSP70 are induced by a dose dependent process. The AgNP mediated organ damage is accompanied by ER stress sensor protein activation including PERK, IRE1, and CHOP proteins. It has been further reported that ER stress mediates a significant decrease in the DNA content of mice liver after AgNP feeding, suggesting the possible induction of apoptosis [152].

The AgNP mediated apoptosis mostly occurs in the liver, lung, kidney, and spleen, but also, no apoptosis has been seen in the heart and brain. Furthermore, a study has also reported that AgNP induced oxidative stress (OS) is demonstrated by the upregulation mRNA of HO1, SOD1, and GPX. In addition, the level of different inflammatory markers like IL- 6 and TNF- $\alpha$, the expression increases at higher concentration of AgNPs [152,153].

There is a little information available regarding the sensitivity of different tissues for AgNPs [154,155]. It has been observed that $16 \mathrm{HBE}$ possesses the highest sensitivity to AgNPs compared to human umbilical vein endothelial cells (HUVECs) and HepG2 cells. In parallel, the ER stress was responded significantly by $16 \mathrm{HBE}$ cells compared to the other two cell lines. The upregulation of different proteins in 16HBE cells was in parallel to the overexpression of different proteins in HUVECs by AgNP induced ER stress [72]. It also leads to the overactivation of different genes including HSPs like HSPA1b, HSPH1, and ER proteins Mdg1/ERdj4 (DNAJB9), a chaperone belonging to the HSP40 family [156]. The exposure of AgNPs also leads to the induction of ER stress marker genes like DNA damage-inducible protein 34 (GADD34/PPP1R15a). Furthermore, these NPs also lead to the overexpression of homocysteine-inducible, ER stress-inducible, ubiquitin-like domain member 1 (HERPUD1). Moreover, a significant expression of DDIT3/CHOP genes occur by AgNP exposure. The physicochemical properties of AgNPs and their specific role for inducing ER stress is further summarized in Table 3.

\subsection{Gold Nanoparticles}

Gold nanoparticles (AuNPs) are emerging as novel agents for cancer treatment and are being explored as drug carriers, radiosensitizers, and photothermal agents. The biological effects of $\mathrm{X}$-irradiation efficiency is enhanced by high atomic number elements. In this regard, AuNPs have been used as a favorable radiosensitizer, in addition to iodine and iododeoxyuridine $[157,158]$. It has been found that the radiosensitization is very effective for both free cell suspension in the presence of 1\% AuNPs (1.5-3.0 $\mu \mathrm{m}$ diameter) as well as for tumor cells injected with AuNPs [159]. The size of such AuNPs limits their use for intracellular medium, so the size reduction is the only choice for their specific organelle-targeting. Smaller AuNPs ( $1.9 \mathrm{~nm}$ diameter) have been found to be internalized and uniformly distributed within the transplanted tumor cell cytoplasm [160]. Moreover, it has also been observed that the accumulation of $13 \mathrm{~nm}$ AuNPs in B16F10 melanoma cells leads to apoptosis through enhanced radiosensitization [161].

The stability of gold nanosol has been dramatically enhanced by coupling it with polyethylene glycol (PEG). PEGylated AuNPs have been used to sensitize CT26 colorectal adenocarcinoma and EMT-6 breast cancer cells to different forms of ionizing radiations [162]. The PEGylated AuNPs have also been found to possess higher bioefficiency, however, the detachment of PEG leads to decreased dispersion stability. A unique PEGylated gold nanogel has been prepared that possesses a large payload capacity of AuNPs (8 nm diameter) [163]. This form of nanogel is made up of a cross-linked poly(2-[N,N-diethylamino]ethyl methacrylate) (PEAMA) gel core tethered with PEG chains. The tunneling electron microscopy (TEM) results revealed that the diameter of Au-nanogel particles was almost $106 \mathrm{~nm}$, and approximately 15 AuNPs were calculated to be included in each PEGylated nanogel [163]. A general representation of PEGylated AuNPs is shown here in Figure 2. 


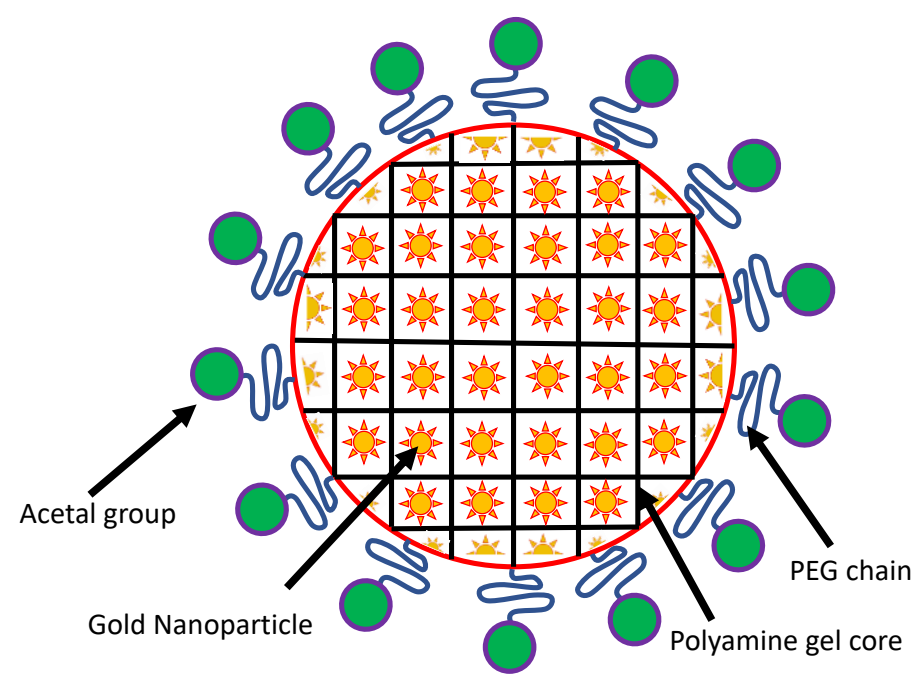

Figure 2. Schematic representation of the AuNP nanogel. The AuNPs are embedded in a core of polyamine gel, which are PEGylated with terminal acetal groups.

This Au-nanogel has been found to possess exceptionally high dispersion stability with unique properties like reversible volume phase transition in response to ionic strength, temperature, and $\mathrm{pH}$ change [164].

Recently, it has also been observed that AuNPs show different biological effects like cell cycle regulation in addition to the production of ROS and the induction of apoptosis [165]. It has been reported that PEGylated phospholipid (PL) nanomicelles, even though not containing AuNPs, accumulated in ER and activated EPR, thus inducing ER stress, which ultimately leads to apoptosis [166]. The physicochemical properties of AuNPs and their specific role for inducing ER stress are further summarized in Table 3.

\subsection{Iron Oxide Nanoparticles}

Iron oxide nanoparticles (FeONPs) have been widely investigated for their novel biomedical applications. These applications include magnetic resonance imaging (MRI), cell tracking, magnetic transfections, tissue repair, detoxification of biological fluids, drug delivery, and hyperthermia treatment $[167,168]$. FeONPs have also been used for their efficient antifungal, antibacterial, and anticancer properties. These NPs have some promising properties such as low cost, ease of synthesis, biocompatibility, and are supramagnetic.

The different NPs from iron include maghemite $\left(\gamma-\mathrm{Fe}_{2} \mathrm{O}_{3}\right)$, hematite $\left(\alpha-\mathrm{Fe}_{2} \mathrm{O}_{3}\right)$, and magnetite $\left(\mathrm{Fe}_{3} \mathrm{O}_{4}\right) \mathrm{NPs}$. For the imaging of different diseases, ultra-small super paramagnetic FeONPs have been applied as an intravenous injection, which can be accumulated in spleen and liver. These NPs are used for the imaging of liver diseases such as cirrhosis, hepatitis, and hepatocellular carcinoma $[169,170]$.

The genomic expression results have shown that ultrasmall paramagnetic FeONPs (USP-FeONPs) affects many signaling pathways of inflammatory response such as IL-6 release from the diseased cells [171]. These NPs lead to ER expansion, upregulate calcium ions, and induce ER stress in hepatocytes. It has also been observed that USP-FeONPs induce higher inflammation and cytotoxicity and also trigger IL-6 related inflammation, which is regulated by UPR and ATF4/PERK pathways. This indicates that ATF4/PERK pathways could be a specific and potential target to attenuate USP-FeONP-induced hepatic inflammatory response [172].

The cytotoxic effects of hematite NPs on Hekk293 cells have been observed by using $180 \mathrm{~nm}$ sized NPs at a dose of 100-500 $\mu \mathrm{g} / \mathrm{mL}$ for one day exposure time where it was observed that these NPs did not show any toxicity at a lower dose $(<300 \mu \mathrm{g} / \mathrm{mL})$, but significant cytotoxicity was observed at a $>350 \mu \mathrm{g} / \mathrm{mL}$ dosage. These hematite NPs induce the oxidative stress in Hek293 cells and lower the antioxidant capacity and the activity of antioxidant enzymes [173]. 
The hematite NPs (15-30 nm diameter) have been used to study their anticancer activity against HepG2 liver cancer cells [174]. The different concentrations from 50 to $1000 \mathrm{ng} / \mathrm{mL}$ were used to study this cytotoxicity in HekG2 cancer cells. The dimercaptosuccinic acid (DMSA)-coated supramagnetic FeONPs were used for their internalization and clearance studies within the HepG2 cells [175]. It was found that micropinocytosis uptake and clathrin-mediated internalization depends upon the particle size (Figure 1). It was reported that these NPs are accumulated in MDF-7 cells without any significant effects on cell morphology, ROS generation, and cell viability. It has been concluded from these studies that DMSA-coated supramagnetic FeONPs possess excellent biocompatibility to target breast cancer cells. Furthermore, their anti-tumor effect on MCF-7 cells suggests that these NPs may be used to target drug accumulation in cancer cells. However, the lower concentrations showed more efficiency in tumor cell disturbance, and lowering the therapeutic dose can reduce the side effects of chemotherapy [176].

The role of FeONPs in tumor cells has been further studied and it has been observed that tumor cells are effectively killed by heat production with the help of magnetic hyperthermia in whole tumor regions of the breast. The heating potential is functionalized by efficient NP cell internalization and the effects of the chemotherapeutic agent [177]. In addition, it has been reported that the therapeutic effects of magnetic hyperthermia in breast cancer could be strongly enhanced by the combination of MF66 functionalized with N6L and doxorubicin (DOX) and magnetic hyperthermia. The toxicological and therapeutic roles of FeONPs is further discussed in Table 2.

\subsection{Manganese Nanoparticles}

Different oxidation states of manganese $(\mathrm{Mn})$ give rise to the formation of $\mathrm{MnO}_{2}, \mathrm{Mn}_{2} \mathrm{O}_{3}$, and $\mathrm{Mn}_{3} \mathrm{O}_{4}$ forms [178]. $\mathrm{Mn}_{3} \mathrm{O}_{4} \mathrm{NPs}$ (MnNPs) are recognized as very significant nanomaterials as they possess excellent electrochemical behavior. Proper investigation about the adverse consequences of manganese nanoparticles (MnNPs) on human health has not yet been satisfactorily done as these particles are increasingly used in industrial and biomedical fields. The role MnNPs on ER stress mediated ROS generation, glutathione (GSH) variation, $\mathrm{Ca}^{2+}$ imbalance, and apoptosis has been studied on hippocampal neurons. It has been found that these NPs cause the depletion of GSH and increase oxidative stress and calcium level. The expression of ER stress related proteins like caspase $(-3,-9,-12)$, PERK, EIF 2 $\alpha$, GRP78, and GADD153 is enhanced with the introduction of MnNPs [179].

The MnNPs possess a very small size and large surface energy. These NPs possess higher biological activities and can easily enter within the cells by free penetration. This NP entry occurs through the receptor mediated endocytosis, which actively interact with the intracellular components [180]. In addition, the different intracellular MnNP interactions leads to the protein dysfunctions, DNA damage, signaling pathway interference, and excessive ROS production [181,182].

The different growth inhibition assays on various microorganisms including yeast have confirmed the role of MnNPs as inhibitory due to ion dissolution, ROS production, and mitochondrial damage [183]. In addition, these NPs upregulate the UPR genes, thus mediating its toxic effects through the ER stress. As MnNPs impair ER function, it blocks invertase secretion, which is followed by diminished sucrose absorption and results in slowed down cell growth. Furthermore, these NPs lead to decreased protein secretion required for the overall growth [184].

\subsection{Titanium Oxide Nanoparticles}

In recent years, different studies on titanium oxide $\left(\mathrm{TiO}_{2}\right)$ nanoparticles $\left(\mathrm{TiO}_{2} \mathrm{NPs}\right)$ have highlighted its role in biomedical applications like biosensors, drug delivery system, cancer therapy, cell imaging, and genetic engineering and related biological experiments [185]. All these observations also support its toxic role both in in vivo and in vitro systems. These particles ( $<100 \mathrm{~nm}$ diameter) generate free radicals and enhance DNA adduct formation in lung fibroblasts [186]. $\mathrm{TiO}_{2} \mathrm{NPs}$ induce mitochondrial injury via ROS production in A549 cells and have been reported to produce inflammation and genotoxicity in animal models and different cell lines [187,188]. 
$\mathrm{TiO}_{2} \mathrm{NPs}$ induce ER stress in human bronchial epithelial cells by promoting IRE-1 $\alpha$ phosphorylation, elevating the levels of CHOP and GRP78/Bip expression, followed by $\mathrm{Ca}^{2+}$ homeostasis disruption. As the $\mathrm{Ca}^{2+}$ level is regulated by mitochondria cooperatively with $\mathrm{ER}$, it gets translocated from ER to mitochondria through mitochondria associated-ER membranes [189].

$\mathrm{TiO}_{2}$ photocatalyst NPs have been widely used in cancer therapy based on their biocompatible and photocatalytic properties [187]. The light-driven $\mathrm{TiO}_{2} \mathrm{NPs}$ interfere with the cellular functions through ROS production, so exerting toxicity in cancer cells [190]. These NPs can trigger the malignant cells through ROS mediated apoptosis, which also affects the adjacent cells within these tissues [191,192]. The ROS-mediated accumulation of unfolded/misfolded proteins in ER triggers the adaptive intracellular stress response to minimize this stress by either correcting or degrading the misfolded proteins within the ER lumen [193]. These NPs trigger apoptosis through the induction of ER sensor polypeptides, which include PERK, ATF6, eIF1, and XBP1, and their downstream signaling pathways like the CHOP pathway [194]. The induction of these pathways is also reported in different diseases such as glioma cells, liver cancer, and breast cancer $[195,196]$. The physicochemical properties of $\mathrm{TiO}_{2} \mathrm{NPs}$ and their specific role for inducing ER stress is further summarized in Table 3.

\subsection{Zinc Oxide Nanoparticles}

Zinc oxide $(\mathrm{ZnO})$ nanoparticles (ZnONPs) have a great potential for various applications of consumer products, so it is therefore crucial to assess their possible health risks. These NPs are extensively used in sunscreens, cosmetics products, and superior textiles. Aside from the direct use of these NPs, they are used as self-charging and in different electronic devices. Therefore, there is a great possibility of human exposure and the health impacts at each stage of their production and use. This subject of ZnONP use remains a concern for different health issues. In addition to the pulmonary damage, $\mathrm{ZnONP}$ exposure is also effectively correlated with the increased incidences of cardiovascular diseases and some allergic reactions [197].

ZnONPs induce their toxicity to the cells through the release of toxic $\mathrm{Zn}^{2+}$, which induces the production of ROS [198]. Human umbilical vein endothelial cells (HUVECs) have been used to investigate the cellular responses and ER stress provoked by these NPs. It has been found that dissolved $\mathrm{Zn}^{2+}$ ions are the most significant factors accountable for their cytotoxicity in HUVECs. ZnONPs, even at a noncytotoxic concentration of $120 \mu \mathrm{M}$, induce substantial cellular ER stress response with enhanced expression of spliced CHOP, caspase-12, and XBP1 at the mRNA levels. In addition, the associated ER marker proteins such as CHOP, p-PERK, BiP, GADD34, p-eIF2R, and cleaved Caspase-12 are expressed at the protein levels $[155,197]$. It has been further observed that $240 \mu \mathrm{M}$ ZnONPs quickly reduce the ER stress response before it induces apoptosis. Furthermore, it has been demonstrated that ZnONPs trigger the ER stress-responsive pathways, which could be a novel and sensitive end point strategy for nanotoxicological study. The physicochemical properties of ZnONPs and their specific role for inducing ER stress is further summarized in Table 3.

\subsection{Quartz and Silica Nanoparticles}

Our entire atmosphere is full of nanominerals, so it is important to study the role of these nanominerals including quartz nanoparticles (QNPs), on our health [199]. Quartz is a member of the silicate family of minerals, which is crystalline and consists of $70-80 \%$ silica arranged in tetrahedral $\mathrm{SiO}_{4}$ units. The inhalation effects of quartz particles are well documented to lead to the development of different medical conditions including silicosis and lung cancer [200,201]. Numerous cytotoxicity studies of silica nanoparticle (SiNP) exposure in work places support the possibility of health issues through oxidative stress and inflammation. Different studies on animal models have already shown the damaging effects of SiNPs on proinflammatory stimulation, nucleoplasm, and the formation of fibrotic nodules [202].

Some recent findings have clearly shown that QNPs induce oxidative stress, cytotoxicity, and an inflammatory response that ultimately leads to ER stress and cell death. During stressful conditions of 
a cell, induced by some foreign factors, the ROS homeostasis gets disturbed, leading to the activation of different stress-related pathways. Excess ROS leads to the production of pro-inflammatory markers like IL-6, IL-1 $\beta$, TNF- $\alpha$, and IFN- $\gamma$ leads to inflammasome activation within the cells after prolonged QNP exposure $[203,204]$. The role of QNPs as ER stress inducing agents have been confirmed while studying their effects on the cultured lung A549 cell line [205]. In addition, QNPs have been reported to induce intracellular $\mathrm{Ca}^{2+}$ level and ER stress responsive marker proteins that result in mitochondrial damage [206,207]. The increased $\mathrm{Ca}^{2+}$ level within the cytosol enhances the mitochondrial membrane permealization and ultimately triggers apoptosis [208,209]. Aside from this, the QNP induced ER stress leads to dimerization of PERK proteins after getting released from GRP78 and gets autophosphorylated and induces the phosphorylation of eIF2 $\alpha$. QNP induced ER stress also leads to ATF4 translocation within the nucleus that activates the Caspases and CHOP proteins and induces apoptosis. In addition to ER stress, QNPs also lead to apoptosis, mediated by Caspases and JNK, followed by impairment of mitochondria [210,211].

Silica $\left(\mathrm{SiO}_{2}\right)$ NPs are used to arouse oxidative stress within the cells, thus resulting in cytotoxicity, which is a time and size dependent phenomenon [212]. These NPs also lead to an imbalance of $\mathrm{Ca}^{2+}$ homeostasis and membrane damage $[213,214]$. It has been reported that $\mathrm{SiO}_{2}-\mathrm{NPs}$ also induce the pro-inflammatory response and genotoxicity in CaCo-2 cell lines [215]. These NPs have also been used to induce inflammation and oxidative stress within human macrophages and lung epithelial cells [216,217].

Recently, it has been reported in human hepatoma cells that $\mathrm{SiO}_{2}-\mathrm{NPs}$ promote oxidative stress through the ER stress [218], and leads to the induction of TNF- $\alpha$ and activates MAPK pathways [219]. $\mathrm{SiO}_{2}-\mathrm{NPs}$ induced ER stress also leads to the activation of NF- $\mathrm{B}$, leading to the expression of interferons [220]. It has been further reported that $\mathrm{SiO}_{2}-\mathrm{NPs}$ persuade the expression of MAP kinase regulated transcription factors like CYMC and CJUN [219]. Furthermore, it has been found that $\mathrm{SiO}_{2}-\mathrm{NP}$ exposure affects different pathways like the expression of the ATF-4 target gene GADD34, and the expression of genes belonging to the MAPK signaling pathways. In addition, these NPs also affect the expression of DNAJB8, IL-8 as well as the pro-apoptotic gene and CHOP expression.

\subsection{Graphene Oxide Nanoparticles}

Graphene oxide nanoparticles (GONPs) are biocompatible and biodegradable, which have been targeted to ER by conjugating with the dansyl moiety by using the ethylene diamine linker. The ER surface contains sulfonamide receptors that have a binding affinity with the dansyl moiety. In addition, the dansyl moiety possesses a fluorescent nature, which helps to track its location within the ER in cancer cells [221,222]. Recently, GONPs have been loaded with doxorubicin (DOX) and cisplatin individually with almost $79 \%$ drug loading efficiency.

The drug DOX inhibits the IRE- $\alpha$ of the UPR [223], and cisplatin binds with different proteins like PDI and calreticulin, which reside in the ER and induce the stress [224,225]. Once the GONPs loaded with DOX and cisplatin are internalized within the ER, it leads to the CHOP expression many fold. In addition, these NPs induce the expression of GRP78, which indicates the onset of ER stress. GONPs also induce the formation of autophagosomes and autophagy, which is validated by the expression of LC3B as a marker of autophagy [226,227]. Furthermore, these GONPs alone and in combination with chloroquine exhibited remarkable efficacy in cell killing in lung, breast, and triple negative breast cancer cells. The results of Panday et al. (2020) clearly demonstrate that graphene oxide ER-specific NPs can be used as effective tools to rouse UPR signaling, and so can lead to future cancer therapeutics [228].

\subsection{Lipid Nanoparticles}

The different types of polymeric NPs including the lipidic NPs have been recently used to target the ER for different purposes including the triggering of ER stress in cancer cells [221]. Different cancer cells have been exposed to small molecules and peptide-based self-assembled nanomaterials to provoke 
ER stress $[229,230]$. Recently, a NP-conjugate has been engineered for the ER localization consisting of a dodecyl amine, tosyl group (for ER localization), and naphthalimide moiety (a fluorescent label for subcellular localization) comprising tanespimycin or 17-AAG (HSP 90 inhibitor), which is used to induce ER stress. These NPs with a $158 \mathrm{~nm}$ diameter are endocytosed by caveolin-mediated intake by HeLa cells and are transported to the ER. These 17AAG-ER-NPs promote the ER stress in addition to nuclear DNA damage, resulting in cell cycle arrest during G2/M phase. These consequences are followed with enhanced apoptosis compared with the free 17-AAG. Furthermore, 17AAG-ER-NPs have been suggested as an efficient platform tool to understand oncogenesis in detail as well as in future-generation cancer therapy [222].

\subsection{Enzyme Assembly Based Nanoparticles}

As ER targeting is considered as a promising future strategy for cancer management, the specific disruption of ER within cancer cells is still a great challenge to be worked out [231]. The current targeting of small molecules like thapsigargin and tunicamycin to ER lacks the proper cell selectivity. These drugs possess strong neurotoxicity, but the lack of specificity hinders their clinical applications. One way has been resolved to target these drugs to the ER by conjugation with toxins like the Shiga toxin [232]. However, this conjugate still faces a remarkable problem, which is to manage the endosomal/lysosomal escape. Therefore, it is very important to manage the novel ER targeting strategy, lysosomal escaping potential, and proper cancer cell specificity. To meet all the criteria of specific ER targeting, the use of enzyme-instructed self-assembly (EISA) has been explored to achieve a proper spatiotemporal control [233].

EISA is an active process commonly used to regulate the proteins and small molecules. Application of EISA for lipids, sterols, peptides, or carbohydrates has exhibited great promise for inhibiting cancer cells, so plays a potential role in cancer therapy [234,235]. As only specific enzymes are enriched in tumor cells that are confined at specific locations, EISA can localize the supramolecular assemblies at the position of these enzymes, and the resulting assemblies efficiently reduce the diffusion and significantly enhance the diffusion-limited interactions [236]. This novel application of EISA is an innovative strategy to target different cell organelles like the nucleus, mitochondria, and cell membrane to boost the efficient accumulation of small molecules to minimize drug resistance [237,238]. This strategy has strongly favored the use of EISA to specifically target the ER in cancer cells for future cancer management.

\subsection{Carbon Nanotubes}

Carbon nanotube (CNT) exposure to HUVECs has been observed to induce oxidative stress as some antioxidants have been reported to alleviate its genotoxicity and cytotoxicity attitude [239,240]. The toxicity of CNTs with shorter diameter and longer length have been reported to be more powerful compared to their other dimensional parameters. These nanotubes have been more toxic to HUVECs as they activate ER stress. Carboxylation of CNTs further increases their cytotoxicity behavior due to the blockade of autophagic flux [241].

CNTs significantly increase oxidative stress due to the decreasing level of GSH, which provokes increased ROS. In addition, CNTs promote ER stress by inducing ER stress biomarkers like CHOP, pCHOP, and DDIT3. Previously, these findings have also been observed as CNTs induce the ER stress in C. elegans and cultured human cells [242]. All types of CNTs have been found to considerably downregulate the pro-survival ER stress gene XBP-1s. This phenomena is supposed to decrease the level of anti-apoptotic protein $\mathrm{BCl}-2$ and the enhancement of caspase- 3 and caspase- 8 . This up/down regulation of specific proteins finally leads to the decreased cellular viability. Furthermore, it has been found that pristine hydroxylation and carboxylation of CNTs are equally cytotoxic to HUVECs and all types of CNTs activate the ER stress signaling pathways [243]. 
Table 3. Different types of metal and non-metal NPs possessing diverse physico-chemical properties that have specific roles in ER stress provocation and special applications, which were investigated to study their role in the management of cancer and other diseases.

\begin{tabular}{|c|c|c|c|c|}
\hline Nanoparticle & Physicochemical Properties and Related Studies & Specific Role in ER Stress Induction & Application & Reference \\
\hline \multirow{6}{*}{ AgNPs } & $\begin{array}{c}\text { Typical size of } 120 \mathrm{~nm} \text {, negatively charged ZFL } \\
\text { cells (in vitro); exposure on zebrafish (in vivo) } \\
0.05-0.5 \mathrm{mg} / \mathrm{mL} \text { for } 6-24 \mathrm{~h} \text { (in vitro); } 0.1-5 \mathrm{mg} / \mathrm{mL} \\
\text { for } 24 \mathrm{~h} \text { (in vivo) }\end{array}$ & $\begin{array}{l}\text { Increase in GRP78, ATF6, and XBP-1s } \\
\text { protein expression or mRNA synthesis. }\end{array}$ & $\begin{array}{l}\text { ROS induction, ER stress response, apoptotic } \\
\text { and inflammatory pathways activation. }\end{array}$ & [72] \\
\hline & $\begin{array}{l}\text { Average size } 20 \mathrm{~nm} \text {, negatively charged } 16 \mathrm{HBE} \\
\text { cells (in vitro); mice (in vivo) } 2 \mu \mathrm{g} / \mathrm{cm}^{2} \text { exposure } \\
\text { from } 4 \text { to } 24 \mathrm{~h} \text { (in vitro); } 0.1-0.5 \mu \mathrm{g} / \mathrm{g} \text { (in vivo) }\end{array}$ & $\begin{array}{l}\text { Increased p-PERK, XBP-1s, p-IRE1 } \alpha, \\
\text { CHOP, GRP78, p-eIF2 } \alpha \text { protein } \\
\text { expression or mRNA synthesis }\end{array}$ & $\begin{array}{l}\text { Cellular response on different cell lines, to } \\
\text { know the mechanisms of action in various } \\
\text { cellular systems, cellular activation of different } \\
\text { signaling molecules }\end{array}$ & [244] \\
\hline & $\begin{array}{c}10,50 \text { and } 100 \mathrm{~nm} \text { used in HepG2 cells as } 1 \mu \mathrm{g} / \mathrm{mL} \\
\text { dose for } 24 \mathrm{~h}\end{array}$ & Increase in $\mathrm{CHOP}$ protein & $\begin{array}{c}\text { Can be used as cytotoxic agents on mice liver } \\
\text { primary cells and also in human liver } \\
\text { HepG2 cells }\end{array}$ & [245] \\
\hline & $\begin{array}{l}15 \mathrm{~nm} \text { in size, negatively charged in THP- } 1 \text { cells as } \\
\qquad 1-25 \mu \mathrm{g} / \mathrm{mL} \text { for } 1 \text { or } 24 \mathrm{~h}\end{array}$ & $\begin{array}{c}\text { Increase in p-PERK protein and ATF6 } \\
\text { degradation }\end{array}$ & $\begin{array}{l}\text { Redox active particles can induce toxicity } \\
\text { mediated through ROS production and } \\
\text { increases oxidative stress }\end{array}$ & [246] \\
\hline & $\begin{array}{l}\leq 100 \mathrm{~nm} \text { size, used in Human Chang liver cells as } \\
\qquad 4 \mu \mathrm{g} / \mathrm{mL} \text { for } 3-24 \mathrm{~h}\end{array}$ & $\begin{array}{l}\text { Increase in ER tracker staining and } \\
\text { protein levels of p-IRE1, p-PERK, ATF6, } \\
\text { peIF2 } \alpha, \text { XBP-1s, GRP78, and CHOP }\end{array}$ & $\begin{array}{l}\text { Increased concentrations of these NPs induce } \\
\text { substantial cytotoxicity, DNA damage } \\
\text { and apoptosis. }\end{array}$ & [247] \\
\hline & $\begin{array}{c}\text { Size } 2 \mathrm{~nm} \text { to } 10 \mathrm{~nm} \text {; negatively charged used in } \\
\text { MCF-7 and T-47D cells }\end{array}$ & $\begin{array}{l}\text { Increase in p-eIF } 2 \alpha, \mathrm{p} \text {-PERK, CHOP, } \\
\text { p-IRE1 } \alpha, \text { and ATF4 proteins }\end{array}$ & $\begin{array}{l}\text { Possess anti-cancer activity, DOX }+ \text { AgNPs can } \\
\text { induce conformational changes on DNA }\end{array}$ & [248] \\
\hline \multirow[t]{3}{*}{ AuNPs } & $\begin{array}{l}\text { Size } 20 \text { to } 70 \mathrm{~nm} \text { and negatively charged used in } \\
\text { human neutrophils as } 100 \mu \mathrm{g} / \mathrm{mL} \text { for } 3 \mathrm{~h}\end{array}$ & $\begin{array}{l}\text { Increased p-IRE, p-PERK, and ATF6 } \\
\text { proteins synthesis }\end{array}$ & $\begin{array}{l}\text { PEG-AuNPs can be efficient drug delivery } \\
\text { vehicles, and exhibit least adsorption of } \\
\text { proteins and slight size and charge deviation } \\
\text { when used in whole blood }\end{array}$ & [250] \\
\hline & $20 \mathrm{~nm}$ in size, citrate coated AsPc1 cells & $\begin{array}{c}\text { Enhanced IRE- } 1 \alpha \text { and CHOP proteins } \\
\text { synthesis }\end{array}$ & $\begin{array}{c}\text { Sensitization of pancreatic cancer cells by the } \\
\text { pre-treatment with these NPs in addition to } \\
\text { gemcitabine in colony forming and } \\
\text { viability assays }\end{array}$ & [251] \\
\hline & Size of $1-6 \mathrm{~nm}$ and $15-20 \mathrm{~nm}$ used in K562 cells & $\begin{array}{l}\text { Increased the ER stress related proteins } \\
\text { checked by proteomic assay }\end{array}$ & $\begin{array}{l}\text { These NPs can be used to diminish the growth } \\
\text { and provoke strong apoptosis in human } \\
\text { chronic myeloid leukemia cells }\end{array}$ & [252] \\
\hline
\end{tabular}


Table 3. Cont

\begin{tabular}{|c|c|c|c|c|}
\hline Nanoparticle & Physicochemical Properties and Related Studies & Specific Role in ER Stress Induction & Application & Reference \\
\hline PEGylated nanogel with AuNPs & Used in SCCVII and A549 cells & $\begin{array}{l}\text { Increased GRP78, IRE- } 1 \alpha, \text { p-PERK } \\
\text { protein synthesis }\end{array}$ & $\begin{array}{l}\text { Favors the radiosensitization of cells to } \\
\text { increase the apoptosis and ER stress provoked } \\
\text { DNA repair capacity }\end{array}$ & [253] \\
\hline \multirow{4}{*}{$\mathrm{ZnO} \mathrm{NPs}$} & $\begin{array}{c}\text { Size about } 100 \mathrm{~nm} \text { used in HUVEC at a dose of } 240 \\
\mu \mathrm{M} \text { for } 4-24 \mathrm{~h}\end{array}$ & $\begin{array}{l}\text { Augmented CHOP, p-PERK, XBP-1s, } \\
\text { p-eIF2 } \alpha, \text { HSP proteins or mRNA } \\
\text { production }\end{array}$ & Activates the ER stress-responsive pathways & [197] \\
\hline & $\begin{array}{l}\text { Size between } 30 \mathrm{~nm} \text { to } 90 \mathrm{~nm} \text {, bulk } 100-200 \mathrm{~nm} \\
\text { used in mice at } 100 \mathrm{mg} / \mathrm{kg} / \mathrm{d} \text { for } 3 \mathrm{~d}\end{array}$ & $\begin{array}{l}\text { Increase in eIF2a, PERK, ATF4, JNK, } \\
\text { CHOP, GRP94 mRNA in livers }\end{array}$ & $\begin{array}{l}\text { It disrupts seminiferous epithelium of the testis } \\
\text { and decreases the sperm density in } \\
\text { the epididymis }\end{array}$ & [254] \\
\hline & $\begin{array}{l}\text { The size is about } 70 \mathrm{~nm} \text {; positively charged used in } \\
\text { MRC } 5 \text { cells at } 25 \text { and } 50 \mu \mathrm{g} / \mathrm{mL} \text { for } 16 \mathrm{~h}\end{array}$ & $\begin{array}{l}\text { Increases } \mathrm{CHOP} \text { and ERN1 mRNA } \\
\text { synthesis }\end{array}$ & $\begin{array}{l}\text { Oxidative stress is promoted, which causes } \\
\text { cytotoxicity and genotoxicity in human lung } \\
\text { fibroblasts in vitro and in D. melanogaster } \\
\text { in vivo }\end{array}$ & [255] \\
\hline & $\begin{array}{l}\text { The size is }<100 \mathrm{~nm} \text { and negatively charged used } \\
\text { in mice as gavage for } 90 \mathrm{~d}(200,400 \mathrm{mg} / \mathrm{kg})\end{array}$ & $\begin{array}{c}\text { It causes the swelling of ER; increases } \\
\text { GRP 78/94, XBP-1, and PDI-3 mRNA } \\
\text { synthesis, CHOP and p-JNK protein } \\
\text { production in liver }\end{array}$ & $\begin{array}{l}\text { The relationship of the dosage and organs } \\
\text { affected as pancreas, stomach, eye, } \\
\text { and prostate gland }\end{array}$ & [256] \\
\hline ZnS NPs & $\begin{array}{l}\text { Size between } 50 \text { and } 100 \mathrm{~nm} \text { used in mice retinal } \\
\text { pigment epithelial cells }\end{array}$ & $\begin{array}{l}\text { Inhibited GRP78 and CHOP } \\
\text { protein synthesis }\end{array}$ & $\begin{array}{c}\text { Can be used as anti-age-related macular } \\
\text { degeneration }\end{array}$ & [257] \\
\hline $\mathrm{Fe}_{3} \mathrm{O}_{4} \mathrm{NPs}$ & $\begin{array}{l}15-20 \mathrm{~nm} \text { in size, PLGA coated about } 300 \mathrm{~nm} \text { in } \\
\text { size used in MCF-7 cells as } 100 \mu \mathrm{g} / \mathrm{mL} \text { for } 24 \mathrm{~h} \text {. }\end{array}$ & Disrupts and disperse ER & $\begin{array}{l}\text { Gemcitabine loaded NPs demonstrate as } \\
\text { multifunctional drag cargo system, can be used } \\
\text { during radiosensitization investigations }\end{array}$ & [259] \\
\hline \multirow{3}{*}{$\mathrm{TiO}_{2} \mathrm{NPs}$} & $\begin{array}{l}\text { Size as P25 }(24 \mathrm{~nm}) \text {, and scrolled nanosheets (L/W } \\
\text { 178/9), nanoneedles (L/W 45/15), isotropic NPs }(29 \\
\mathrm{nm}) \text { used in HUVECs cells as } 2 \mu \mathrm{g} / \mathrm{cm}^{2} \text { for } 1-24 \mathrm{~h}\end{array}$ & $\begin{array}{c}\text { Increase in ERdj4, CHOP, HERPUD1 } \\
\text { mRNA (scrolled } \\
\text { nanosheets }\end{array}$ & $\begin{array}{l}\text { Such NPs can be used to increase the ROS } \\
\text { production having a central role in the } \\
\text { induction of receptor expression }\end{array}$ & [260] \\
\hline & $\begin{array}{l}\text { Size as } 19.3 \pm 5.4 \mathrm{~nm} \text {, used in mice, inhaled to } 2.5 \\
5.0 \text { and } 10.0 \mathrm{mg} / \mathrm{m}^{3} \mathrm{NPs} \text { for a span of } 28 \mathrm{~d}\end{array}$ & $\begin{array}{l}\text { Causes the swelling of ER and increases } \\
\text { CHOP, GRP78, and p-IRE1 } \alpha \text { protein } \\
\text { synthesis in lungs }\end{array}$ & $\begin{array}{l}\text { Can be used as toxicological index that acts as } \\
\text { a benchmark for assessing the risks to } \\
\text { human health }\end{array}$ & [261] \\
\hline & $\begin{array}{l}\text { Hydrodynamic size of about } 250 \mathrm{~nm} \text {, the anatase: } \\
\text { rutile ratio of } 8: 2 \text { used in } 16 \mathrm{HBE} 14 \mathrm{o}-\mathrm{lung} \text { cells as } 50 \\
\text { and } 100 \mu \mathrm{g} / \mathrm{mL} \text { for } 24 \text { and } 48 \mathrm{~h}\end{array}$ & $\begin{array}{l}\text { Increases the CHOP, GRP78, IRE- } 1 \alpha \text {, } \\
\text { and } p \text {-IRE- } 1 \alpha \text { protein synthesis }\end{array}$ & $\begin{array}{c}\text { The Anatase } \mathrm{TiO}_{2} \mathrm{NPs} \text { induces increased } \\
\text { inflammatory responses as compared with } \\
\text { other } \mathrm{TiO}_{2} \text { particles }\end{array}$ & [262] \\
\hline
\end{tabular}


Table 3. Cont

\begin{tabular}{|c|c|c|c|c|}
\hline Nanoparticle & Physicochemical Properties and Related Studies & Specific Role in ER Stress Induction & Application & Reference \\
\hline $\begin{array}{c}\text { Cadmium telluride (CdTe) } \\
\text { quantum dots (QDs) (CdTeQDs) }\end{array}$ & $\begin{array}{l}\text { About } 4 \mathrm{~nm} \text { in size and negative charged used in } \\
\text { HUVECs cells as } 10 \mu \mathrm{g} / \mathrm{mL} \text { for } 24 \mathrm{~h} \text {. }\end{array}$ & $\begin{array}{l}\text { Lead to the dilation of ER and protein } \\
\text { synthesis increase of GRP78/95, CHOP, } \\
\text { ATF4, p-PERK, peIF2 } \alpha \text {, and p-JNK. }\end{array}$ & $\begin{array}{l}\text { The toxicity of QDs can act as potential } \\
\text { cardiovascular risk factors }\end{array}$ & [263] \\
\hline $\begin{array}{l}\text { Poly [lactic-co-glycolic acid] (PLGA) } \\
\text { NPs containing } \gamma \text {-oryzanol }\end{array}$ & $\begin{array}{l}\text { Size about } 214.8 \mathrm{~nm} \text { with negative charge used in } \\
\text { obese ob/ob mice }\end{array}$ & $\begin{array}{l}\text { It reduced the CHOP, ERdj4, } \\
\text { and XBP-1s mRNA synthesis }\end{array}$ & $\begin{array}{c}\text { Can be used during metabolic } \\
\text { diseases treatment }\end{array}$ & [154] \\
\hline $\begin{array}{l}\text { Poly [lactic-co-glycolic acid] (PLGA) } \\
\text { NPs containing LY294002 }\end{array}$ & $\begin{array}{l}\text { NPs with an average size of } 98.9 \pm 2.64 \mathrm{~nm} \text { and } \\
\text { used in H157, H460, H1650, and NL20 cells }\end{array}$ & $\begin{array}{c}\text { It leads to the accumulation in ER; } \\
\text { increased GRP78, CHOP, and p-JNK } \\
\text { proteins }\end{array}$ & $\begin{array}{l}\text { These NPs act as surfactant-free formulation of } \\
\text { PLGA and possesses a promising } \\
\text { anticancer activity }\end{array}$ & [264] \\
\hline \multirow[t]{2}{*}{$\mathrm{CeO}_{2} \mathrm{NPs}$} & $\begin{array}{l}\text { Average size of } 7 \mathrm{~nm} \text { used in } \mathrm{MCP}-1 \text { transgenic } \\
\text { mice }\end{array}$ & $\begin{array}{l}\text { It suppresses the GRP78, PDI, and HSP } \\
\text { mRNA synthesis }\end{array}$ & $\begin{array}{l}\text { These NPs slow down the advancement of } \\
\text { cardiac dysfunction myocardial } \\
\text { oxidative stress }\end{array}$ & [265] \\
\hline & Used in $\mathrm{H} 9 \mathrm{C} 2$ cells & $\begin{array}{l}\text { It reduces the PDI and GRP78 proteins } \\
\text { synthesis }\end{array}$ & $\begin{array}{l}\text { These NPs are } \mathrm{pH} \text { responsive with } \\
\text { anti-tumoral activities for osteosarcoma }\end{array}$ & [266] \\
\hline $\begin{array}{l}\text { PEGylated-Phosphatidyl } \\
\text { ethanolamine (PE) micelles }\end{array}$ & Used in MRC-5, A549, 293T cells for ER dilation & $\begin{array}{l}\text { Leads to increased IRE- } 1 \alpha, \text { eIF } 2 \alpha, \\
\text { PERK, ATF4/6, XBP-1s and CHOP } \\
\text { proteins synthesis in cancer cells }\end{array}$ & $\begin{array}{l}\text { It enhances the sensitivity of most cancer cells } \\
\text { to some chemotherapeutic agents }\end{array}$ & [267] \\
\hline $\begin{array}{l}\text { Gadolinium metallofullerenol } \\
\quad\left[\mathrm{Gd}_{\mathrm{C}} \mathrm{C}_{82}(\mathrm{OH})_{22}\right]_{\mathrm{n}} \mathrm{NPs}\end{array}$ & Used in MCF-7 and ECV304 cells & $\begin{array}{l}\text { It lead to slowed protein processing in } \\
\text { ER and also increased the CHOP } \\
\text { mRNA synthesis as reported by DNA } \\
\text { microarray }\end{array}$ & $\begin{array}{c}\text { These NPs possess high anti-tumor activity but } \\
\text { have low toxicity }\end{array}$ & [268] \\
\hline Realgar QDs & $\begin{array}{c}\text { These NPs have an average size of } 5.48 \mathrm{~nm} \text { and } \\
\text { used in JEC cells }\end{array}$ & $\begin{array}{l}\text { It induces the dilation of ER and } \\
\text { increased CHOP and GRP78 mRNA } \\
\text { and proteins synthesis }\end{array}$ & $\begin{array}{l}\text { Can be used effectively against human } \\
\text { endometrial cancer cells as it leads to ER stress } \\
\text { mediated necrosis and apoptotic cell death }\end{array}$ & [269] \\
\hline $\begin{array}{l}\text { Anodic Alumina Nanotubes } \\
\text { (AANTs) loaded with Thapsigargin } \\
\text { (TG) }\end{array}$ & $\begin{array}{l}\text { The length is } 736 \mathrm{~nm} \pm 460 \mathrm{~nm} \text {, inner diameter and } \\
\text { outer diameter as } 33.0 \pm 8.0 \text { and } 90.0 \pm 10.0 \mathrm{~nm} \\
\text { used in THP-1, HFF, and MDA-MB 231-TXSA cells }\end{array}$ & $\begin{array}{l}\text { It led to increase in IRE1 } \alpha \text { and GRP78 } \\
\text { proteins synthesis and ER tracker } \\
\text { staining }\end{array}$ & $\begin{array}{l}\text { It can act as novel biomaterials for clinical } \\
\text { cancer therapy as it can act as ER and } \\
\text { autophagic delivery systems }\end{array}$ & [270] \\
\hline $\begin{array}{l}\text { Anodic Alumina Nanotubes } \\
\text { (AANTs) }\end{array}$ & $\begin{array}{l}\text { It has the aspect ratio of } 7.8 \text { (short), } 27.7 \text { (medium) } \\
\text { and } 63.3 \text { (long) used in MDA-MB-231-TXSA and } \\
\text { RAW264.7 cells as } 100 \mu \mathrm{g} / \mathrm{mL} \text { AANTs for 3d. }\end{array}$ & $\begin{array}{l}\text { It led to increased CHOP protein } \\
\text { synthesis and ER-tracker staining and } \\
\text { decreased IRE1 } \alpha \text { protein synthesis as } \\
\text { reported by long AANT only. }\end{array}$ & $\begin{array}{c}\text { For the advanced drug delivery applications, it } \\
\text { has a promising opportunity as it can control } \\
\text { the nanotoxicity of high aspect } \\
\text { ratio nanomaterials }\end{array}$ & [271] \\
\hline
\end{tabular}


Table 3. Cont

\begin{tabular}{|c|c|c|c|c|}
\hline Nanoparticle & Physicochemical Properties and Related Studies & Specific Role in ER Stress Induction & Application & Reference \\
\hline $\begin{array}{l}\text { Extremely small size iron oxide NPs } \\
\text { (ESION) and MnONPs }\end{array}$ & $\begin{array}{c}\text { About } 3 \mathrm{~nm} \text { (ESION), and } 15 \mathrm{~nm} \text { (MnONPs) used } \\
\text { in mice as 2, 5, } 10 \mu \mathrm{g} / \mathrm{g} \text { for } 1 \mathrm{~d}\end{array}$ & $\begin{array}{c}\text { Enhanced the expression of } \mathrm{CHOP}, \mathrm{HSP} \\
\text { GRP78, XBP-1s mRNA or protein in } \\
\text { various organs }\end{array}$ & $\begin{array}{c}\text { NPs exposure causes bodyweight loss, } \\
\text { increased NO and MDA levels, inflammatory } \\
\text { and hyperplastic changes in the } \\
\text { lung homogenates }\end{array}$ & [272] \\
\hline $\mathrm{NH}_{2}$-labelled Polystyrene (PS) NPs & $\begin{array}{l}60 \mathrm{~nm} \text { in size, positively charged used in RAW } \\
264.7, \text { BEAS-2B cells as } 5-40 \mu \mathrm{g} / \mathrm{mL} \text { up to } 16 \mathrm{~h} \text {. }\end{array}$ & $\begin{array}{l}\text { It leads to misfolded protein aggregates; } \\
\text { increases ER-tracker staining and } \\
\text { IRE1 } \alpha \text { protein synthesis }\end{array}$ & $\begin{array}{l}\text { These NPs can play an efficient role in } \\
\text { autophagy, safe and novel material design and } \\
\text { inhibition of the toxicity }\end{array}$ & [273] \\
\hline Chitosan NPs & $\begin{array}{l}\text { Average size of } 100 \mathrm{~nm} \text { used in mouse } \\
\text { morula-stage embryos as } 100 \mu \mathrm{g} / \mathrm{mL} \text { for } 24-28 \mathrm{~h}\end{array}$ & $\begin{array}{c}\text { It leads to increase in GRP78, CHOP, } \\
\text { ATF4, PERK, IRE- } 1 \alpha \text {, protein or mRNA } \\
\text { synthesis }\end{array}$ & $\begin{array}{l}\text { These NPs lead to blastocyst complications } \\
\text { with no or small cavity }\end{array}$ & [274] \\
\hline Silica $\left(\mathrm{SiO}_{2}\right) \mathrm{NPs}$ & $\begin{array}{l}\text { About } 250 \mathrm{~nm} \text { in size and negatively charged used } \\
\text { in Huh7 cells as } 0.05-0.5 \mathrm{mg} / \mathrm{mL} \text { for } 4 \text { and } 24 \mathrm{~h}\end{array}$ & $\begin{array}{l}\text { These NPs increased the GRP78 and } \\
\text { XBP-1s mRNA synthesis }\end{array}$ & $\begin{array}{l}\text { These NPs lead to ER stress mediated MAPK } \\
\text { pathway, and inflammatory reactions initiation } \\
\text { in human hepatoma cells }\end{array}$ & [197] \\
\hline Polyethyleneimine (PEI) NPs & Used in Neuro2A cells as $3-25 \mu \mathrm{g} / \mathrm{mL}$ for $24 \mathrm{~h}$ & $\begin{array}{l}\text { It causes increased GRP78, ATF4 and } \\
\text { CHOP mRNA synthesis }\end{array}$ & $\begin{array}{l}\text { These NPs cause Neuro2A cells induced cell } \\
\text { toxicity in a concentration-dependent manner }\end{array}$ & [81] \\
\hline Curcumin NPs & $\begin{array}{l}\text { Average size of } 50 \mathrm{~nm} \text { and negative charged used } \\
\text { in } \mathrm{H} 9 \mathrm{C} 2 \text { cells }\end{array}$ & $\begin{array}{l}\text { These NPs cause suppression of GRP78 } \\
\text { and CHOP proteins }\end{array}$ & These NPs can prevent myocardial injury & [275] \\
\hline
\end{tabular}




\section{Summary}

The vast majority of evidence has now interpreted the role of ER stress response in tumorigenesis and cancer resistance. Some interesting results have clearly shown the innovative possibility of targeting UPR transduction components for cancer therapy by overcoming severe drug resistance. Different researchers have demonstrated the role of diverse metal and non-metal based NPs and other nanocomplexes by triggering ER stress, which mediates the anticancer activity. Up until now, dozens of NPs have been found to possess a novel anticancer property. Even though different NPs possess structural similarities, they activate ER stress through different mechanisms such as redox mediators, $\mathrm{Ca}^{2+}$ trafficking, and ROS generation. These different NPs induce ER stress in diverse ways as they can act as proteosome inhibitors, photosensitizers, enzyme inhibitors, and $\mathrm{Ca}^{2+}$ trafficking modulators, etc. The most common feature of NPs is the disruption of redox homeostasis as an anticancer activity. The metal complex NPs like CuNPs, PtNPs, and AuNPs enable the metal centers to act as electrophiles. The ER stress in response to such NPs targets the redox regulatory enzymes like PDI and thioredoxin-1 (TRX). Overall, these NPs exhibit outstanding power, even at nanomolar concentration and noteworthy in vivo cancer-reduction abilities. These nanoformulations have also been found to possess more selectivity toward cancer cells. Together, the use of these NPs have demonstrated a great potential as ER-targeting antitumor agents.

The signaling pathways activated by NP-mediated ER stress are not fully understood as it involves molecular mechanisms with dualistic functions in cell survival and death. Thus, understanding how these ER stress pathways signal cell death or prevent it from such steps, comprises a major challenge for future investigations and requires to define a validation for drug design and applications. The challenge of specific cancer treatment in the near future is in the development of drugs targeting the cytoprotective functions of the UPR, and leaving intact or accelerating its pro-apoptotic power. In addition, the actual mechanism that decides the ER specific NPs in eliciting the UPR dependent toggling between the pro-survival and pro-apoptotic signaling cascades needs to be fully comprehended. An in depth focus on this core area of research will be helpful in boosting up developing novel pro-drug candidates to exploit ER stress for triggering pro-death pathways in different cancers. The necessity of a deeper understanding of cancer biology, employment of proper regulatory measures, and advancements in nanoparticle technology will definitely speed up the possible mainstream cancer treatments in the near future.

Author Contributions: A.A.K. and K.S.A. contributed in concept, design, diagrams, and information collection of the work. A.A. and S.A.A. reviewed this article thoroughly. A.M. and M.A.A. helped in information gathering and table design, A.H.R. contributed in the review and final approval of the work. All authors have read and agreed to the published version of the manuscript.

Funding: Researchers would like to thank the Deanship of Scientific Research, Qassim University for funding the publication of this project.

Conflicts of Interest: The authors declare no conflict of interest.

$\begin{array}{ll}\text { Abbreviations } \\ \text { ASK1 } & \begin{array}{l}\text { apoptosis signal regulating kinase1 } \\ \text { ATF6 }\end{array} \\ \text { activating transcription factor } 6 \\ \text { BiP } & \text { binding immunoglobulin protein } \\ \text { CHOP } & \text { C/EBP homologues protein } \\ \text { CNTs } & \text { carbon nanotubes } \\ \text { eIF2 } \alpha & \text { eukaryotic initiation factor } 2 \alpha \\ \text { EISA } & \text { enzyme instructed self-assembly } \\ \text { ER } & \text { Endoplasmic Reticulum } \\ \text { ERAD } & \text { endoplasmic reticulum associated protein degradation } \\ \text { GADD34 } & \text { growth arrest and DNA damage-inducible protein } \\ \text { GRP 78 } & \text { glucose regulated protein } \\ \text { GSH } & \text { glutathione }\end{array}$




$\begin{array}{ll}\text { HSP } & \text { heat shock protein } \\ \text { HUVEC } & \text { human umbilical vein endothelial cells } \\ \text { IRE1 } \alpha & \text { inositol-requiring protein } 1 \alpha \\ \text { JNK } & \text { c-Jun N-terminal kinase } \\ \text { NPs } & \text { nanoparticles } \\ \text { OS } & \text { oxidative stress } \\ \text { PDI } & \text { protein disulfide isomerase } \\ \text { PEG } & \text { polyethylene glycol } \\ \text { PERK } & \text { protein kinase RNA-like ER kinase } \\ \text { ROS } & \text { reactive oxygen species } \\ \text { SOD 1 } & \text { superoxide dismutase 1 } \\ \text { SREBP 1c } & \text { sterol regulatory elementary binding protein 1c } \\ \text { TNF } \alpha & \text { tumor necrosis factor } \alpha \\ \text { TRAF2 } & \text { tumor necrosis factor-receptor associated factor 2 } \\ \text { UPR } & \text { unfolded protein response } \\ \text { Xbp1 } & \text { X-box binding protein 1 }\end{array}$

\section{References}

1. Iurlaro, R.; Muñoz-Pinedo, C. Cell death induced by endoplasmic reticulum stress. FEBS J. 2016, 283, $2640-2652$. [CrossRef] [PubMed]

2. Braakman, I.; Hebert, D.N. Protein folding in the endoplasmic reticulum. Cold Spring Harb. Perspect. Biol. 2013, 5, a013201. [CrossRef] [PubMed]

3. Luo, B.; Lee, A.S. The critical roles of endoplasmic reticulum chaperones and unfolded protein response in tumorigenesis and anticancer therapies. Oncogene 2013, 32, 805-818. [CrossRef] [PubMed]

4. Lukas, J.; Pospech, J.; Oppermann, C.; Hund, C.; Iwanov, K.; Pantoom, S.; Petters, J.; Frech, M.; Seemann, S.; Thiel, F.G.; et al. Role of endoplasmic reticulum stress and protein misfolding in disorders of the liver and pancreas. Adv. Med. Sci. 2019, 64, 315-323. [CrossRef]

5. Cao, S.S.; Kaufman, R.J. Endoplasmic reticulum stress and oxidative stress in cell fate decision and human disease. Antioxid. Redox Signal. 2014, 21, 396-413. [CrossRef]

6. Houck, S.A.; Ren, H.Y.; Madden, V.J.; Bonner, J.N.; Conlin, M.P.; Janovick, J.A.; Conn, P.M.; Cyr, D.M. Quality control autophagy degrades soluble ERAD-resistant conformers of the misfolded membrane protein GnRHR. Mol. Cell 2014, 54, 166-179. [CrossRef]

7. Gessner, D.K.; Schlegel, G.; Ringseis, R.; Schwarz, F.J.; Eder, K. Up-regulation of endoplasmic reticulum stress induced genes of the unfolded protein response in the liver of periparturient dairy cows. BMC Vet. Res. 2014, 10, 46. [CrossRef]

8. Malhotra, J.D.; Kaufman, R.J. Endoplasmic reticulum stress and oxidative stress: A vicious cycle or a double-edged sword? Antioxid. Redox Signal. 2007, 9, 2277-2293. [CrossRef]

9. Tse, G.; Yan, B.P.; Chan, Y.W.; Tian, X.Y.; Huang, Y. Reactive oxygen species, endoplasmic reticulum stress and mitochondrial dysfunction: The link with cardiac arrhythmogenesis. Front. Physiol. 2016, 7, 313. [CrossRef]

10. Hotamisligil, G.S. Endoplasmic reticulum stress and the inflammatory basis of metabolic disease. Cell 2010, 140, 900-917. [CrossRef]

11. Liu, Z.W.; Zhu, H.T.; Chen, K.L.; Dong, X.; Wei, J.; Qiu, C.; Xue, J.H. Protein kinase RNA-like endoplasmic reticulum kinase (PERK) signaling pathway plays a major role in reactive oxygen species (ROS)-mediated endoplasmic reticulum stress-induced apoptosis in diabetic cardio-myopathy. Cardiovasc. Diabetol. 2013, 12, 1-16. [CrossRef] [PubMed]

12. Li, H.; Korennykh, A.V.; Behrman, S.L.; Walter, P. Mammalian endoplasmic reticulum stress sensor IRE1 signals by dynamic clustering. Proc. Natl. Acad. Sci. USA 2010, 107, 16113-16118. [CrossRef] [PubMed]

13. Han, D.; Lerner, A.G.; Walle, L.V.; Upton, J.P.; Xu, W.; Hagen, A.; Backes, B.J.; Oakes, S.A.; Papa, F.R. IRE1 $\alpha$ kinase activation modes control alternate endoribonuclease outputs to determine divergent cell fates. Cell 2009, 138, 562-575. [CrossRef] [PubMed]

14. Lee, A.H.; Iwakoshi, N.N.; Glimcher, L.H. XBP-1 regulates a subset of endoplasmic reticulum resident chaperone genes in the unfolded protein response. Mol. Cell. Biol. 2003, 23, 7448-7459. [CrossRef] [PubMed] 
15. Shaffer, A.; Shapiro-Shelef, M.; Iwakoshi, N.N.; Lee, A.-H.; Qian, S.-B.; Zhao, H.; Yu, X.; Yang, L.; Tan, B.K.; Rosenwald, A.; et al. XBP1, Downstream of Blimp-1, Expands the Secretory Apparatus and Other Organelles, and Increases Protein Synthesis in Plasma Cell Differentiation. Immunity 2004, 21, 81-93. [CrossRef]

16. Nishitoh, H.; Matsuzawa, A.; Tobiume, K.; Saegusa, K.; Takeda, K.; Inoue, K.; Hori, S.; Kakizuka, A.; Ichijo, H. ASK1 is essential for endoplasmic reticulum stress-induced neuronal cell death triggered by expanded polyglutamine repeats. Genes Dev. 2002, 16, 1345-1355. [CrossRef]

17. Barr, R.K.; Bogoyevitch, M.A. The c-Jun N-terminal protein kinase family of mitogen-activated protein kinases (JNK MAPKs). Int. J. Biochem. Cell Biol. 2001, 33, 1047-1063. [CrossRef]

18. Tong, Q.; Wu, L.; Jiang, T.; Ou, Z.; Zhang, Y.; Zhu, D. Inhibition of endoplasmic reticulum stress-activated IRE1 $\alpha$-TRAF2-caspase-12 apoptotic pathway is involved in the neuroprotective effects of telmisartan in the rotenone rat model of Parkinson's disease. Eur. J. Pharmacol. 2016, 776, 106-115. [CrossRef]

19. Wang, P.; Li, J.; Tao, J.; Sha, B. The luminal domain of the ER stress sensor protein PERK binds misfolded proteins and thereby triggers PERK oligomerization. J. Biol. Chem. 2018, 293, 4110-4121. [CrossRef]

20. Anderson, P.; Kedersha, N. Visibly stressed: The role of eIF2, TIA-1, and stress granules in protein translation. Cell Stress Chaperones 2002, 7, 213-221. [CrossRef]

21. McQuiston, A.; Diehl, J.A. Recent insights into PERK-dependent signaling from the stressed endoplasmic reticulum. F1000Research 2017, 6, 1897. [CrossRef] [PubMed]

22. Harding, H.P.; Novoa, I.; Zhang, Y.; Zeng, H.; Wek, R.; Schapira, M.; Ron, D. Regulated Translation Initiation Controls Stress-Induced Gene Expression in Mammalian Cells. Mol. Cell 2000, 6, 1099-1108. [CrossRef]

23. Liao, Y.; Gu, F.; Mao, X.; Niu, Q.; Wang, H.; Sun, Y.; Song, C.; Qiu, X.; Tan, L.; Ding, C. Regulation of de novo translation of host cells by manipulation of PERK/PKR and GADD34-PP1 activity during Newcastle disease virus infection. J. Gen. Virol. 2016, 97, 867-879. [CrossRef]

24. Horimoto, S.; Ninagawa, S.; Okada, T.; Koba, H.; Sugimoto, T.; Kamiya, Y.; Kato, K.; Takeda, S.; Mori, K. The unfolded protein response transducer ATF6 represents a novel transmembrane-type endoplasmic reticulum-associated degradation substrate requiring both mannose trimming and SEL1L protein. J. Biol. Chem. 2013, 288, 31517-31527. [CrossRef] [PubMed]

25. Stirling, J.; O'Hare, P. CREB4, a transmembrane bZip transcription factor and potential new substrate for regulation and cleavage by S1P. Mol. Biol. Cell 2006, 17, 413-426. [CrossRef]

26. Chen, Y.; Brandizzi, F. IRE1: ER stress sensor and cell fate executor. Trends Cell Biol. 2013, 23, 547-555. [CrossRef]

27. Chen, X.; Shen, J.; Prywes, R. The luminal domain of ATF6 senses endoplasmic reticulum (ER) stress and causes translocation of ATF6 from the ER to the Golgi. J. Biol. Chem. 2002, 277, 13045-13052. [CrossRef]

28. Ye, J.; Rawson, R.B.; Komuro, R.; Chen, X.; Davé, U.P.; Prywes, R.; Brown, M.S.; Goldstein, J.L. ER Stress Induces Cleavage of Membrane-Bound ATF6 by the Same Proteases that Process SREBPs. Mol. Cell 2000, 6, 1355-1364. [CrossRef]

29. Teske, B.F.; Wek, S.A.; Bunpo, P.; Cundiff, J.K.; McClintick, J.N.; Anthony, T.G.; Wek, R.C. The eIF2 kinase PERK and the integrated stress response facilitate activation of ATF6 during endoplasmic reticulum stress. Mol. Biol. Cell 2011, 22, 4390-4405. [CrossRef]

30. Nakanishi, K.; Sudo, T.; Morishima, N. Endoplasmic reticulum stress signaling transmitted by ATF6 mediates apoptosis during muscle development. J. Cell Biol. 2005, 169, 555-560. [CrossRef]

31. Ozcan, L.; Tabas, I. Role of endoplasmic reticulum stress in metabolic disease and other disorders. Annu. Rev. Med. 2012, 18, 317-328. [CrossRef] [PubMed]

32. Amin, A.; Choi, S.K.; Galan, M.; Kassan, M.; Partyka, M.; Kadowitz, P.; Henrion, D.; Trebak, M.; Belmadani, S.; Matrougui, K. Chronic inhibition of endoplasmic reticulum stress and inflammation prevents ischaemia-induced vascular pathology in type II diabetic mice. J. Pathol. 2012, 227, 165-174. [CrossRef] [PubMed]

33. Imai, Y.; Soda, M.; Takahashi, R. Parkin suppresses unfolded protein stress-induced cell death through its E3 ubiquitin-protein ligase activity. J. Biol. Chem. 2000, 275, 35661-35664. [CrossRef]

34. Nijholt, D.A.; de Graaf, T.R.; van Haastert, E.S.; Oliveira, A.O.; Berkers, C.R.; Zwart, R.; Ovaa, H.; Baas, F.; Hoozemans, J.J.; Scheper, W. Endoplasmic reticulum stress activates autophagy but not the proteasome in neuronal cells: Implications for Alzheimer's disease. Cell Death Differ. 2011, 18, 1071-1081. [CrossRef] [PubMed] 
35. Tsukano, H.; Gotoh, T.; Endo, M.; Miyata, K.; Tazume, H.; Kadomatsu, T.; Yano, M.; Iwawaki, T.; Kohno, K.; Araki, K.; et al. The Endoplasmic Reticulum Stress-C/EBP Homologous Protein Pathway-Mediated Apoptosis in Macrophages Contributes to the Instability of Atherosclerotic Plaques. Arter. Thromb. Vasc. Biol. 2010, 30, 1925-1932. [CrossRef] [PubMed]

36. Wang, H.; Chen, L.; Zhang, X.; Xu, L.; Xie, B.; Shi, H.; Duan, Z.; Zhang, H.; Ren, F. Kaempferol protects mice from d-GalN/LPS-induced acute liver failure by regulating the ER stress-Grp78-CHOP signaling pathway. Biomed. Pharmacother. 2019, 111, 468-475. [CrossRef]

37. Kammoun, H.L.; Chabanon, H.; Hainault, I.; Luquet, S.; Magnan, C.; Koike, T.; Ferré, P.; Foufelle, F. GRP78 expression inhibits insulin and ER stress-induced SREBP-1c activation and reduces hepatic steatosis in mice. J. Clin. Investig. 2009, 119, 1201-1215. [CrossRef]

38. Yeganeh, B.; Moghadam, A.R.; Alizadeh, J.; Wiechec, E.; Alavian, S.M.; Hashemi, M.; Geramizadeh, B.; Samali, A.; Lankarani, K.B.; Post, M.; et al. Hepatitis B and C virus-induced hepatitis: Apoptosis, autophagy, and unfolded protein response. World J. Gastroenterol. 2015, 21, 13225. [CrossRef]

39. Saxena, S.; Cabuy, E.; Caroni, P. A role for motoneuron subtype-selective ER stress in disease manifestations of FALS mice. Nat. Neurosci. 2009, 12, 627-636. [CrossRef]

40. So, A.Y.-L.; De La Fuente-Ortega, E.; Walter, P.; Shuman, M.; Bernales, S. The unfolded protein response during prostate cancer development. Cancer Metastasis Rev. 2009, 28, 219-223. [CrossRef]

41. Delie, F.; Petignat, P.; Cohen, M. GRP78 Protein Expression in Ovarian Cancer Patients and Perspectives for a Drug-Targeting Approach. J. Oncol. 2012, 2012, 1-5. [CrossRef] [PubMed]

42. Su, R.; Li, Z.; Li, H.; Song, H.; Bao, C.; Wei, J.; Cheng, L. Grp78 promotes the invasion of hepatocellular carcinoma. BMC Cancer 2010, 10, 20. [CrossRef] [PubMed]

43. Zhang, Y.; Tseng, C.-C.; Tsai, Y.-L.; Fu, X.; Schiff, R.; Lee, A.S. Cancer Cells Resistant to Therapy Promote Cell Surface Relocalization of GRP78 Which Complexes with PI3K and Enhances PI(3,4,5)P3 Production. PLoS ONE 2013, 8, e80071. [CrossRef]

44. Overley-Adamson, B.; Artlett, C.M.; Stephens, C.; Sassi-Gaha, S.; Weis, R.D.; Thacker, J.D. Targeting the unfolded protein response, XBP1, and the NLRP3 inflammasome in fibrosis and cancer. Cancer Biol. Ther. 2014, 15, 452-462. [CrossRef] [PubMed]

45. Déry, M.-A.; Jodoin, J.; Ursini-Siegel, J.; Aleynikova, O.; Ferrario, C.; Hassan, S.; Basik, M.; Leblanc, A.C. Endoplasmic reticulum stress induces PRNP prion protein gene expression in breast cancer. Breast Cancer Res. 2013, 15, R22. [CrossRef] [PubMed]

46. Nagelkerke, A.; Bussink, J.; Mujcic, H.; Wouters, B.G.; Lehmann, S.; Sweep, F.C.; Span, N.P. Hypoxia stimulates migration of breast cancer cells via the PERK/ATF4/LAMP3-arm of the unfolded protein response. Breast Cancer Res 2013, 15, R2. [CrossRef]

47. Ming, J.; Ruan, S.; Wang, M.; Ye, D.; Fan, N.; Meng, Q.; Tian, B.; Huang, T. A novel chemical, STF-083010, reverses tamoxifen-related drug resistance in breast cancer by inhibiting IRE1/XBP1. Oncotarget 2015, 6, 40692. [CrossRef]

48. Pike, L.R.G.; Singleton, D.C.; Buffa, F.M.; Abramczyk, O.; Phadwal, K.; Li, J.; Simon, A.K.; Murray, J.T.; Harris, A.L. Transcriptional up-regulation of ULK1 by ATF4 contributes to cancer cell survival. Biochem. J. 2012, 449, 389-400. [CrossRef]

49. Li, Z.; Zhang, L.; Zhao, Y.; Li, H.; Xiao, H.; Fu, R.; Zhao, C.; Wu, H.; Li, Z. Cell-surface GRP78 facilitates colorectal cancer cell migration and invasion. Int. J. Biochem. Cell Biol. 2013, 45, 987-994. [CrossRef]

50. Lee, H.K.; Xiang, C.; Cazacu, S.; Finniss, S.; Kazimirsky, G.; Lemke, N.; Lehman, N.L.; Rempel, S.A.; Mikkelsen, T.; Brodie, C. GRP78 is overexpressed in glioblastomas and regulates glioma cell growth and apoptosis. Neuro-Oncology 2008, 10, 236-243. [CrossRef]

51. Mahoney, D.J.; Lefebvre, C.; Allan, K.; Brun, J.; Sanaei, C.A.; Baird, S.; Pearce, N.; Grönberg, S.; Wilson, B.; Prakesh, M.; et al. Virus-Tumor Interactome Screen Reveals ER Stress Response Can Reprogram Resistant Cancers for Oncolytic Virus-Triggered Caspase-2 Cell Death. Cancer Cell 2011, 20, 443-456. [CrossRef] [PubMed]

52. Gupta, S.; McGrath, B.; Cavener, D.R. PERK regulates the proliferation and development of insulin-secreting beta-cell tumors in the endocrine pancreas of mice. PLoS ONE 2009, 4, e8008. [CrossRef]

53. Niu, Z.; Wang, M.; Zhou, L.; Yao, L.; Liao, Q.; Zhao, Y. Elevated GRP78 expression is associated with poor prognosis in patients with pancreatic cancer. Sci. Rep. 2015, 5, 1-2. [CrossRef] [PubMed]

54. Lee, A.S. GRP78 Induction in Cancer: Therapeutic and Prognostic Implications. Cancer Res. 2007, 67, 3496-3499. [CrossRef] [PubMed] 
55. Yang, J.; Cheng, D.; Zhou, S.-M.; Zhu, B.; Hu, T.; Yang, Q.-C. Overexpression of X-Box Binding Protein 1 (XBP1) Correlates to Poor Prognosis and Up-Regulation of PI3K/mTOR in Human Osteosarcoma. Int. J. Mol. Sci. 2015, 16, 28635-28646. [CrossRef]

56. Kraskiewicz, H.; Fitzgerald, U. InterfERing with endoplasmic reticulum stress. Trends Pharmacol. Sci. 2012, 33, 53-63. [CrossRef] [PubMed]

57. Schleicher, S.M.; Moretti, L.; Varki, V.; Lu, B. Progress in the unraveling of the endoplasmic reticulum stress/autophagy pathway and cancer: Implications for future therapeutic approaches. Drug Resist. Update 2010, 13, 79-86. [CrossRef]

58. Healy, S.J.; Gorman, A.M.; Mousavi-Shafaei, P.; Gupta, S.; Samali, A. Targeting the endoplasmic reticulum-stress response as an anticancer strategy. Eur. J. Pharmacol. 2009, 625, 234-246. [CrossRef]

59. Cho, H.-Y.; Thomas, S.; Golden, E.B.; Gaffney, K.J.; Hofman, F.M.; Chen, T.C.; Louie, S.G.; Petasis, N.A.; Schönthal, A.H. Enhanced killing of chemo-resistant breast cancer cells via controlled aggravation of ER stress. Cancer Lett. 2009, 282, 87-97. [CrossRef]

60. Shen, K.; Johnson, D.W.; Vesey, D.A.; McGuckin, M.A.; Gobe, G.C. Role of the unfolded protein response in determining the fate of tumor cells and the promise of multi-targeted therapies. Cell Stress Chaperones 2018, 23, 317-334. [CrossRef]

61. Seo, S.; Richter, A.; Blechschmidt, A.-M.; Bougoudis, I.; Burrows, J.P. First high resolution BrO column retrievals from TROPOMI. J. Cancer 2018, 2018, 1-26. [CrossRef]

62. Suh, D.H.; Kim, M.K.; Kim, H.S.; Chung, H.H.; Song, Y.S. Unfolded protein response to autophagy as a promising druggable target for anticancer therapy. Ann. N. Y. Acad. Sci. 2012, 1271, 20-32. [CrossRef] [PubMed]

63. Martelli, A.M.; Paganelli, F.; Chiarini, F.; Evangelisti, C.; McCubrey, J.A. The Unfolded Protein Response: A Novel Therapeutic Target in Acute Leukemias. Cancers 2020, 12, 333. [CrossRef] [PubMed]

64. Zhu, M.; Nie, G.; Meng, H.; Xia, T.; Nel, A.; Zhao, Y. Physicochemical Properties Determine Nanomaterial Cellular Uptake, Transport, and Fate. Acc. Chem. Res. 2013, 46, 622-631. [CrossRef] [PubMed]

65. Zhao, J.; Stenzel, M.H. Entry of nanoparticles into cells: The importance of nanoparticle properties. Polym. Chem. 2018, 9, 259-272. [CrossRef]

66. Jiang, W.; Kim, B.Y.S.; Rutka, J.T.; Chan, W.C.W. Nanoparticle-mediated cellular response is size-dependent. Nat. Nanotechnol. 2008, 3, 145-150. [CrossRef]

67. Bartczak, D.; Louafi, F.; Millar, T.M.; Kanaras, A.G.; Sanchez-Elsner, T. Receptor-Mediated Interactions between Colloidal Gold Nanoparticles and Human Umbilical Vein Endothelial Cells. Small 2010, 7, 388-394. [CrossRef]

68. Muro, S.; Garnacho, C.; Champion, J.A.; Leferovich, J.; Gajewski, C.; Schuchman, E.H.; Mitragotri, S.; Muzykantov, V.R. Control of Endothelial Targeting and Intracellular Delivery of Therapeutic Enzymes by Modulating the Size and Shape of ICAM-1-targeted Carriers. Mol. Ther. 2008, 16, 1450-1458. [CrossRef]

69. Unfried, K.; Sydlik, U.; Bierhals, K.; Weissenberg, A.; Abel, J. Carbon nanoparticle-induced lung epithelial cell proliferation is mediated by receptor-dependent Akt activation. Am. J. Physiol. Cell. Mol. Physiol. 2008, 294, L358-L367. [CrossRef]

70. Zhang, D.; Neumann, O.; Wang, H.; Yuwono, V.M.; Barhoumi, A.; Perham, M.; Hartgerink, J.D.; Wittung-Stafshede, P.; Halas, N.J. Gold Nanoparticles Can Induce the Formation of Protein-based Aggregates at Physiological pH. Nano Lett. 2009, 9, 666-671. [CrossRef] [PubMed]

71. Deng, Z.J.; Liang, M.; Monteiro, M.; Toth, I.; Minchin, R.F. Nanoparticle-induced unfolding of fibrinogen promotes Mac-1 receptor activation and inflammation. Nat. Nanotechnol. 2011, 6, 39-44. [CrossRef] [PubMed]

72. Christen, V.; Capelle, M.; Fent, K. Silver nanoparticles induce endoplasmatic reticulum stress response in zebrafish. Toxicol. Appl. Pharmacol. 2013, 272, 519-528. [CrossRef] [PubMed]

73. Zhang, R.; Piao, M.J.; Kim, K.C.; Kim, A.D.; Choi, J.-Y.; Choi, J.; Hyun, J.W. Endoplasmic reticulum stress signaling is involved in silver nanoparticles-induced apoptosis. Int. J. Biochem. Cell Biol. 2012, 44, 224-232. [CrossRef] [PubMed]

74. Sarkar, A.; Das, J.; Manna, P.; Sil, P.C. Nano-copper induces oxidative stress and apoptosis in kidney via both extrinsic and intrinsic pathways. Toxicology 2011, 290, 208-217. [CrossRef] [PubMed]

75. Siddiqui, M.A.; Alhadlaq, H.A.; Ahmad, J.; Al-Khedhairy, A.A.; Musarrat, J.; Ahamed, M. Copper Oxide Nanoparticles Induced Mitochondria Mediated Apoptosis in Human Hepatocarcinoma Cells. PLoS ONE 2013, 8, e69534. [CrossRef] [PubMed] 
76. Tsai, Y.-Y.; Huang, Y.-H.; Chao, Y.-L.; Hu, K.-Y.; Chin, L.-T.; Chou, S.-H.; Hour, A.-L.; Yao, Y.-D.; Tu, C.-S.; Liang, Y.-J.; et al. Identification of the Nanogold Particle-Induced Endoplasmic Reticulum Stress by Omic Techniques and Systems Biology Analysis. ACS Nano 2011, 5, 9354-9369. [CrossRef]

77. Xia, T.; Zhao, Y.; Sager, T.; George, S.; Pokhrel, S.; Li, N.; Schoenfeld, D.; Meng, H.; Lin, S.; Wang, X.; et al. Decreased Dissolution of $\mathrm{ZnO}$ by Iron Doping Yields Nanoparticles with Reduced Toxicity in the Rodent Lung and Zebrafish Embryos. ACS Nano 2011, 5, 1223-1235. [CrossRef]

78. Kim, C.K.; Kim, T.; Choi, I.; Soh, M.; Kim, D.; Kim, Y.-J.; Jang, H.; Yang, H.-S.; Kim, J.Y.; Park, H.-K.; et al. Ceria Nanoparticles that can Protect against Ischemic Stroke. Angew. Chem. Int. Ed. 2012, 51, 11039-11043. [CrossRef]

79. Conde, J.; Doria, G.; Baptista, P. Noble metal nanoparticles applications in cancer. J. Drug Deliv. $2012,2012$. [CrossRef]

80. Khan, A.A.; Allemailem, K.S.; Almatroodi, S.A.; Almatroudi, A.; Rahmani, A.H. Recent strategies towards the surface modification of liposomes: An innovative approach for different clinical applications. 3 Biotech 2020, 10, 1-15. [CrossRef]

81. Dabbaghi, M.; Oskuee, R.K.; Hashemi, K.; Goli, A.A. Evaluating polyethyleneimine/DNA nanoparticles-mediated damage to cellular organelles using endoplasmic reticulum stress profile. Artif. Cells Nanomed. Biotechnol. 2017, 46, 192-199. [CrossRef] [PubMed]

82. Chen, G.; Shen, Y.; Li, X.; Jiang, Q.; Cheng, S.; Gu, Y.; Liu, L.; Cao, Y. The endoplasmic reticulum stress inducer thapsigargin enhances the toxicity of $\mathrm{ZnO}$ nanoparticles to macrophages and macrophage-endothelial co-culture. Environ. Toxicol. Pharmacol. 2017, 50, 103-110. [CrossRef] [PubMed]

83. Erbis, S.; Ok, Z.; Isaacs, J.A.; Benneyan, J.C.; Kamarthi, S. Review of Research Trends and Methods in Nano Environmental, Health, and Safety Risk Analysis. Risk Anal. 2016, 36, 1644-1665. [CrossRef] [PubMed]

84. Gu, Y.; Cheng, S.; Chen, G.; Shen, Y.; Li, X.; Jiang, Q.; Li, J.; Cao, Y. The effects of endoplasmic reticulum stress inducer thapsigargin on the toxicity of $\mathrm{ZnO}$ or $\mathrm{TiO} 2$ nanoparticles to human endothelial cells. Toxicol. Mech. Methods 2017, 27, 191-200. [CrossRef]

85. Hirsch, I.; Weiwad, M.; Prell, E.; Ferrari, D.M. ERp29 deficiency affects sensitivity to apoptosis via impairment of the ATF6-CHOP pathway of stress response. Apoptosis 2013, 19, 801-815. [CrossRef]

86. Hoseinzadeh, E.; Makhdoumi, P.; Taha, P.; Hossini, H.; Stelling, J.; Kamal, M.A.; Ashraf, G.M. A Review on Nano-Antimicrobials: Metal Nanoparticles, Methods and Mechanisms. Curr. Drug Metab. 2017, 18, 120-128. [CrossRef]

87. Ghosh, C.; Nandi, A.; Basu, S. Supramolecular self-assembly of triazine-based small molecules: Targeting the endoplasmic reticulum in cancer cells. Nanoscale 2019, 11, 3326-3335. [CrossRef]

88. Sydlik, S.A.; Jhunjhunwala, S.; Webber, M.J.; Anderson, D.G.; Langer, R. In Vivo Compatibility of Graphene Oxide with Differing Oxidation States. ACS Nano 2015, 9, 3866-3874. [CrossRef]

89. Mallick, A.; Nandi, A.; Basu, S. Polyethylenimine coated graphene oxide nanoparticles for targeting mitochondria in cancer cells. ACS Appl. Bio Mater. 2019, 2, 14-19. [CrossRef]

90. Chen, L.; Yokel, R.A.; Hennig, B.; Toborek, M. Manufactured Aluminum Oxide Nanoparticles Decrease Expression of Tight Junction Proteins in Brain Vasculature. J. Neuroimmune Pharmacol. 2008, 3, $286-295$. [CrossRef]

91. Jalal, M.; Ansari, M.A.; Shukla, A.K.; Ali, S.G.; Khan, H.M.; Pal, R.; Alam, J.; Cameotra, S.S. Green synthesis and antifungal activity of Al2O3NPs against fluconazole-resistant Candida spp isolated from a tertiary care hospital. RSC Adv. 2016, 6, 107577-107590. [CrossRef]

92. Radziun, E.; Wilczyńska, J.D.; Książek, I.; Nowak, K.; Anuszewska, E.; Kunicki, A.; Olszyna, A.R.; Zabkowski, T. Assessment of the cytotoxicity of aluminium oxide nanoparticles on selected mammalian cells. Toxicol. In Vitro 2011, 25, 1694-1700. [CrossRef]

93. Ansari, M.A.; Khan, H.M.; Alzohairy, M.A.; Jalal, M.; Ali, S.G.; Pal, R.; Musarrat, J. Green synthesis of Al2O3 nanoparticles and their bactericidal potential against clinical isolates of multi-drug resistant Pseudomonas aeruginosa. World J. Microbiol. Biotechnol. 2014, 31, 153-164. [CrossRef] [PubMed]

94. Alshatwi, A.A.; Subbarayan, P.V.; Ramesh, E.; Al-Hazzani, A.A.; AlSaif, M.A.; Alwarthan, A.A. Al2O3Nanoparticles Induce Mitochondria-Mediated Cell Death and Upregulate the Expression of Signaling Genes in Human Mesenchymal Stem Cells. J. Biochem. Mol. Toxicol. 2012, 26, 469-476. [CrossRef] 
95. Prashanth, P.; Raveendra, R.; Krishna, R.H.; Ananda, S.; Bhagya, N.; Nagabhushana, B.; Lingaraju, K.; Naika, H.R. Synthesis, characterizations, antibacterial and photoluminescence studies of solution combustion-derived $\alpha-\mathrm{Al}_{2} \mathrm{O}_{3}$ nanoparticles. J. Asian Ceram. Soc. 2015, 3, 345-351. [CrossRef]

96. Balasubramanyam, A.; Sailaja, N.; Mahboob, M.; Rahman, M.F.; Hussain, S.M.; Grover, P. In vivo genotoxicity assessment of aluminium oxide nanomaterials in rat peripheral blood cells using the comet assay and micronucleus test. Mutagenesis 2009, 24, 245-251. [CrossRef]

97. Rajan, Y.C.; Inbaraj, B.S.; Chen, B.-H. Synthesis and characterization of poly( $\gamma$-glutamic acid)-based alumina nanoparticles with their protein adsorption efficiency and cytotoxicity towards human prostate cancer cells. RSC Adv. 2015, 5, 15126-15139. [CrossRef]

98. Kim, Y.J.; Choi, H.S.; Song, M.K.; Youk, D.Y.; Kim, J.H.; Ryu, J.C. Genotoxicity of aluminum oxide (Al2O3) nanoparticle in mammalian cell lines. Mol. Cell. Toxicol. 2009, 5, 172-178.

99. Beyzay, F.; Zavaran-Hosseini, A.; Soudi, S. Alpha Alumina Nanoparticle Conjugation to Cysteine Peptidase A and B: An Efficient Method for Autophagy Induction. Avicenna J. Med. Biotechnol. 2017, 9, 71-81.

100. Ahamed, M.; Siddiqui, M.A.; Akhtar, M.J.; Ahmad, I.; Pant, A.B.; Alhadlaq, H.A. Genotoxic potential of copper oxide nanoparticles in human lung epithelial cells. Biochem. Biophys. Res. Commun. 2010, 396, 578-583. [CrossRef]

101. Kamble, S.; Utage, B.; Mogle, P.; Kamble, R.; Hese, S.; Dawane, B.; Gacche, R.N. Evaluation of Curcumin Capped Copper Nanoparticles as Possible Inhibitors of Human Breast Cancer Cells and Angiogenesis: A Comparative Study with Native Curcumin. AAPS PharmSciTech 2015, 17, 1030-1041. [CrossRef] [PubMed]

102. Magrez, A.; Kasas, S.; Salicio, V.; Pasquier, N.; Seo, J.W.; Celio, M.; Catsicas, S.; Schwaller, B.; Forró, L. Cellular Toxicity of Carbon-Based Nanomaterials. Nano Lett. 2006, 6, 1121-1125. [CrossRef] [PubMed]

103. Chakraborty, R.; Basu, T. Metallic copper nanoparticles induce apoptosis in a human skin melanoma A-375 cell line. Nanotechnology 2017, 28, 105101. [CrossRef] [PubMed]

104. Li, J.J.; Hartono, D.; Ong, C.-N.; Bay, B.-H.; Yung, L.-Y.L. Autophagy and oxidative stress associated with gold nanoparticles. Biomaterials 2010, 31, 5996-6003. [CrossRef]

105. Arvizo, R.; Bhattacharya, R.; Mukherjee, P. Gold nanoparticles: Opportunities and challenges in nanomedicine. Expert Opin. Drug Deliv. 2010, 7, 753-763. [CrossRef]

106. Boyoglu, C.; He, Q.; Willing, G.; Boyoglu-Barnum, S.; Dennis, V.A.; Pillai, S.R.; Singh, S.R. Microscopic Studies of Various Sizes of Gold Nanoparticles and Their Cellular Localizations. ISRN Nanotechnol. 2013, 2013, 1-13. [CrossRef]

107. Felson, D.T.; Anderson, J.J.; Meenan, R.F. The comparative efficacy and toxicity of second-line drugs in rheumatoid arthritis. Arthritis Rheum. 1990, 3, 1449-1461. [CrossRef]

108. Coradeghini, R.; Gioria, S.; García, C.P.; Nativo, P.; Franchini, F.; Gilliland, D.; Ponti, J.; Rossi, F. Size-dependent toxicity and cell interaction mechanisms of gold nanoparticles on mouse fibroblasts. Toxicol. Lett. 2013, 217, 205-216. [CrossRef]

109. Mukherjee, P.; Bhattacharya, R.; Bone, N.; Lee, Y.K.; Patra, C.R.; Wang, S.; Lu, L.; Secreto, C.; Banerjee, P.C.; Yaszemski, M.J.; et al. Potential therapeutic application of gold nanoparticles in B-chronic lymphocytic leukemia (BCLL): Enhancing apoptosis. J. Nanobiotechnol. 2007, 5, 4. [CrossRef]

110. Boyles, M.S.; Kristl, T.; Andosch, A.; Zimmermann, M.; Tran, N.; Casals, E.; Himly, M.; Puntes, V.; Huber, C.G.; Lutz-Meindl, U.; et al. Chitosan functionalisation of gold nanoparticles encourages particle uptake and induces cytotoxicity and pro-inflammatory conditions in phagocytic cells, as well as enhancing particle interactions with serum components. J. Nanobiotechnol. 2015, 13, 84. [CrossRef]

111. Das, S.K.; Das, A.R.; Guha, A.K. Gold nanoparticles: Microbial synthesis and application in water hygiene management. Langmuir 2009, 25, 8192-8199. [CrossRef] [PubMed]

112. Lin, W.; Huang, Y.-W.; Zhou, X.-D.; Ma, Y. In vitro toxicity of silica nanoparticles in human lung cancer cells. Toxicol. Appl. Pharmacol. 2006, 217, 252-259. [CrossRef] [PubMed]

113. Pattani, V.P.; Tunnell, J.W. Nanoparticle-mediated photothermal therapy: A comparative study of heating for different particle types. Lasers Surg. Med. 2012, 44, 675-684. [CrossRef] [PubMed]

114. Sun, L.; Li, Y.; Liu, X.; Jin, M.; Zhang, L.; Du, Z.; Guo, C.; Huang, P.; Sun, Z. Cytotoxicity and mitochondrial damage caused by silica nanoparticles. Toxicol. In Vitro 2011, 25, 1619-1629. [CrossRef] [PubMed]

115. Hirsch, L.R.; Stafford, R.J.; Bankson, J.A.; Sershen, S.R.; Rivera, B.; Price, R.E.; Hazle, J.D.; Halas, N.J.; West, J.L. Nanoshell-mediated near-infrared thermal therapy of tumors under magnetic resonance guidance. Proc. Natl. Acad. Sci. USA 2003, 100, 13549-13554. [CrossRef] [PubMed] 
116. Hussain, S.M.; Hess, K.; Gearhart, J.; Geiss, K.; Schlager, J. In vitro toxicity of nanoparticles in BRL 3A rat liver cells. Toxicol. In Vitro 2005, 19, 975-983. [CrossRef]

117. Locatelli, E.; Naddaka, M.; Uboldi, C.; Loudos, G.; Fragogeorgi, E.; Molinari, V.; Pucci, A.; Tsotakos, T.; Psimadas, D.; Ponti, J.; et al. Targeted delivery of silver nanoparticles and alisertib: In vitro and in vivo synergistic effect against glioblastoma. Nanomedicine 2014, 9, 839-849. [CrossRef]

118. Foldbjerg, R.B.; Dang, D.A.; Autrup, H. Cytotoxicity and genotoxicity of silver nanoparticles in the human lung cancer cell line, A549. Arch. Toxicol. 2011, 85, 743-750. [CrossRef]

119. Kleinauskas, A.; Rocha, S.; Sahu, S.; Sun, Y.-P.; Juzenas, P. Carbon-core silver-shell nanodots as sensitizers for phototherapy and radiotherapy. Nanotechnology 2013, 24, 325103. [CrossRef]

120. Haase, A.; Tentschert, J.; Jungnickel, H.; Graf, P.; Mantion, A.; Draude, F.; Plendl, J.; Goetz, M.E.; Galla, S.; Mašić, A.; et al. Toxicity of silver nanoparticles in human macrophages: Uptake, intracellular distribution and cellular responses. J. Phys. Conf. Ser. 2011, 304, 012030. [CrossRef]

121. Braun, G.B.; Friman, T.; Pang, H.-B.; Pallaoro, A.; de Mendoza, T.H.; Willmore, A.-M.A.; Kotamraju, V.R.; Mann, A.P.; She, Z.-G.; Sugahara, K.N.; et al. Etchable plasmonic nanoparticle probes to image and quantify cellular internalization. Nat. Mater. 2014, 13, 904-911. [CrossRef] [PubMed]

122. De Berardis, B.; Civitelli, G.; Condello, M.; Lista, P.; Pozzi, R.; Arancia, G.; Meschini, S. Exposure to ZnO nanoparticles induces oxidative stress and cytotoxicity in human colon carcinoma cells. Toxicol. Appl. Pharmacol. 2010, 246, 116-127. [CrossRef] [PubMed]

123. Namvar, F.; Rahman, H.S.; Mohamad, R.; Azizi, S.; Tahir, P.M.; Chartrand, M.S.; Yeap, S.K. Cytotoxic Effects of Biosynthesized Zinc Oxide Nanoparticles on Murine Cell Lines. Evid.-Based Complement. Altern. Med. 2015, 2015, 593014. [CrossRef] [PubMed]

124. Osman, I.F.; Baumgartner, A.; Cemeli-Carratala, E.; Fletcher, J.N.; Anderson, D. Genotoxicity and cytotoxicity of zinc oxide and titanium dioxide in HEp-2 cells. Nanomedicine 2010, 5, 1193-1203. [CrossRef]

125. Tian, L.; Lin, B.; Wu, L.; Li, K.; Liu, H.; Yan, J.; Liu, X.; Xi, Z. Neurotoxicity induced by zinc oxide nanoparticles: Age-related differences and interaction. Sci. Rep. 2015, 5, 16117. [CrossRef]

126. Sharma, V.; Singh, P.; Pandey, A.K.; Dhawan, A. Induction of oxidative stress, DNA damage and apoptosis in mouse liver after sub-acute oral exposure to zinc oxide nanoparticles. Mutat. Res. Toxicol. Environ. Mutagen. 2012, 745, 84-91. [CrossRef]

127. Zhang, Y.; Nayak, T.R.; Hong, H.; Cai, W. Biomedical applications of zinc oxide nanomaterials. Curr. Mol. Med. 2013, 1, 633-1645. [CrossRef]

128. Guan, R.; Kang, T.; Lu, F.; Zhang, Z.; Shen, H.; Liu, M.-Q. Cytotoxicity, oxidative stress, and genotoxicity in human hepatocyte and embryonic kidney cells exposed to ZnO nanoparticles. Nanoscale Res. Lett. 2012, 7, 602. [CrossRef]

129. Antoine, T.E.; Hadigal, S.R.; Yakoub, A.M.; Mishra, Y.K.; Bhattacharya, P.; Haddad, C.; Valyi-Nagy, T.; Adelung, R.; Prabhakar, B.S.; Shukla, D. Intravaginal Zinc Oxide Tetrapod Nanoparticles as Novel Immunoprotective Agents against Genital Herpes. J. Immunol. 2016, 196, 4566-4575. [CrossRef]

130. Huang, C.-C.; Aronstam, R.S.; Chen, D.-R.; Huang, Y.-W. Oxidative stress, calcium homeostasis, and altered gene expression in human lung epithelial cells exposed to ZnO nanoparticles. Toxicol. In Vitro 2010, 24, 45-55. [CrossRef]

131. Khan, Y.A.; Singh, B.R.; Ullah, R.; Mobin, M.; Naqvi, A.H.; Abidi, S.M.A. Anthelmintic Effect of Biocompatible Zinc Oxide Nanoparticles (ZnO NPs) on Gigantocotyle explanatum, a Neglected Parasite of Indian Water Buffalo. PLoS ONE 2015, 10, e0133086. [CrossRef] [PubMed]

132. Naqvi, S.; Samim, M.; Abdin, M.Z.; Ahmed, F.J.; Maitra, A.N.; Prashant, C.K.; Dinda, A.K. Concentrationdependent toxicity of iron oxide nanoparticles mediated by increased oxidative stress. Int. J. Nanomed. 2010, 5, 983-989. [CrossRef] [PubMed]

133. P.Melanconab, M.; Lu, W.; Zhongb, M.; Zhoub, M.; Liangd, G.; Elliott, A.M.; Hazle, J.D.; Myers, J.N.; Lia, C.; Stafford, R.J. Targeted multifunctional gold-based nanoshells for magnetic resonance-guided laser ablation of head and neck cancer. Biomaterials 2011, 32, 7600-7608. [CrossRef] [PubMed]

134. Jeng, H.A.; Swanson, J. Toxicity of Metal Oxide Nanoparticles in Mammalian Cells. J. Environ. Sci. Health Part A 2006, 41, 2699-2711. [CrossRef]

135. Anselmo, A.C.; Mitragotri, S. A Review of Clinical Translation of Inorganic Nanoparticles. AAPS J. 2015, 17, 1041-1054. [CrossRef] 
136. Ge, Y.; Zhang, Y.; He, S.; Nie, F.; Teng, G.; Gu, N. Fluorescence Modified Chitosan-Coated Magnetic Nanoparticles for High-Efficient Cellular Imaging. Nanoscale Res. Lett. 2009, 4, 287-295. [CrossRef]

137. Jordan, A.; Scholz, R.; Maier-Hauff, K.; Van Landeghem, F.K.; Waldoefner, N.; Teichgraeber, U.; Pinkernelle, J.; Bruhn, H.; Neumann, F.; Thiesen, B.; et al. The effect of thermotherapy using magnetic nanoparticles on rat malignant glioma. J. Neuro-Oncol. 2006, 78, 7-14. [CrossRef]

138. Delcroix, G.J.-R.; Jacquart, M.; Lemaire, L.; Sindji, L.; Franconi, F.; Le Jeune, J.-J.; Montero-Menei, C.N. Mesenchymal and neural stem cells labeled with HEDP-coated SPIO nanoparticles: In vitro characterization and migration potential in rat brain. Brain Res. 2009, 1255, 18-31. [CrossRef]

139. Jurgons, R.; Seliger, C.; Hilpert, A.; Trahms, L.; Odenbach, S.; Alexiou, C. Drug loaded magnetic nanoparticles for cancer therapy. J. Phys. Condens. Matter 2006, 18, S2893-S2902. [CrossRef]

140. Liu, R.; Yin, L.; Pu, Y.; Liang, G.; Zhang, J.; Su, Y.; Xiao, Z.; Ye, B. Pulmonary toxicity induced by three forms of titanium dioxide nanoparticles via intra-tracheal instillation in rats. Prog. Nat. Sci. 2009, 19, 573-579. [CrossRef]

141. Fujiwara, R.; Luo, Y.; Sasaki, T.; Fujii, K.; Ohmori, H.; Kuniyasu, H. Cancer Therapeutic Effects of Titanium Dioxide Nanoparticles Are Associated with Oxidative Stress and Cytokine Induction. Pathobiology 2015, 82, 243-251. [CrossRef] [PubMed]

142. Bhattacharya, K.; Davoren, M.; Boertz, J.; Schins, R.P.; Hoffmann, E.; Dopp, E. Titanium dioxide nanoparticles induce oxidative stress and DNA-adduct formation but not DNA-breakage in human lung cells. Part. Fibre Toxicol. 2009, 6, 17. [CrossRef] [PubMed]

143. Sortino, S. Photoactivated nanomaterials for biomedical release applications. J. Mater. Chem. 2012, 22, 301-318. [CrossRef]

144. Lee, Y.-H.; Cheng, F.-Y.; Chiu, H.-W.; Tsai, J.-C.; Fang, C.-Y.; Chen, C.-W.; Wang, Y.-J. Cytotoxicity, oxidative stress, apoptosis and the autophagic effects of silver nanoparticles in mouse embryonic fibroblasts. Biomaterials 2014, 35, 4706-4715. [CrossRef]

145. Braydich-Stolle, L.; Hussain, S.; Schlager, J.J.; Hofmann, M.-C. In Vitro Cytotoxicity of Nanoparticles in Mammalian Germline Stem Cells. Toxicol. Sci. 2005, 88, 412-419. [CrossRef]

146. Zhang, Y.; Liu, R.; Ni, M.; Gill, P.; Lee, A.S. Cell surface relocalization of the endoplasmic reticulum chaperone and unfolded protein response regulator GRP78/BiP. J. Biol. Chem. 2010, 285, 15065-15075. [CrossRef]

147. Xu, Z.; Bu, Y.; Chitnis, N.; Koumenis, C.; Fuchs, S.Y.; Diehl, J.A. miR-216b regulation of c-Jun mediates GADD153/CHOP-dependent apoptosis. Nat. Commun. 2016, 7, 1-12. [CrossRef]

148. Hetz, C.; Bernasconi, P.; Fisher, J.; Lee, A.-H.; Bassik, M.C.; Antonsson, B.; Brandt, G.S.; Iwakoshi, N.N.; Schinzel, A.; Glimcher, L.H.; et al. Proapoptotic BAX and BAK Modulate the Unfolded Protein Response by a Direct Interaction with IRE1. Science 2006, 312, 572-576. [CrossRef]

149. Noh, M.R.; Kim, J.I.; Han, S.J.; Lee, T.-J.; Park, K.M. C/EBP homologous protein (CHOP) gene deficiency attenuates renal ischemia/reperfusion injury in mice. Biochim. Biophys. Acta (BBA) Mol. Basis Dis. 2015, 1852, 1895-1901. [CrossRef]

150. Li, Y.; Bhalli, J.A.; Ding, W.; Yan, J.; Pearce, M.G.; Sadiq, R.; Cunningham, C.K.; Jones, M.Y.; Monroe, W.A.; Howard, P.C.; et al. Cytotoxicity and genotoxicity assessment of silver nanoparticles in mouse. Nanotoxicology 2013, 8, 36-45. [CrossRef]

151. De Jong, W.H.; Van Der Ven, L.T.; Sleijffers, A.; Park, M.V.; Jansen, E.H.; Van Loveren, H.; Vandebriel, R.J. Systemic and immunotoxicity of silver nanoparticles in an intravenous 28 days repeated dose toxicity study in rats. Biomaterials 2013, 34, 8333-8343. [CrossRef] [PubMed]

152. Hackenberg, S.; Scherzed, A.; Kessler, M.; Hummel, S.; Technau, A.; Froelich, K.; Ginzkey, C.; Koehler, C.; Hagen, R.; Kleinsasser, N. Silver nanoparticles: Evaluation of DNA damage, toxicity and functional impairment in human mesenchymal stem cells. Toxicol. Lett. 2011, 201, 27-33. [CrossRef] [PubMed]

153. Chen, R.; Zhao, L.; Bai, R.; Liu, Y.; Han, L.; Xu, Z.; Chen, F.; Autrup, H.; Long, D.; Chen, C. Silver nanoparticles induced oxidative and endoplasmic reticulum stresses in mouse tissues: Implications for the development of acute toxicity after intravenous administration. Toxicol. Res. 2016, 5, 602-608. [CrossRef] [PubMed]

154. 5Kozuka, C.; Shimizu-Okabe, C.; Takayama, C.; Nakano, K.; Morinaga, H.; Kinjo, A.; Fukuda, K.; Kamei, A.; Yasuoka, A.; Kondo, T.; et al. Marked augmentation of PLGA nanoparticle-induced metabolically beneficial impact of $\gamma$-oryzanol on fuel dyshomeostasis in genetically obese-diabetic ob/ob mice. Drug Deliv. 2017, 24, 558-568. [CrossRef] 
155. Kuang, H.; Yang, P.; Yang, L.; Aguilar, Z.P.; Xu, H. Size dependent effect of ZnO nanoparticles on endoplasmic reticulum stress signaling pathway in murine liver. J. Hazard. Mater. 2016, 317, 119-126. [CrossRef]

156. Li, J.; Zhou, Y.; Zhang, W.; Bao, C.; Xie, Z. Relief of oxidative stress and cardiomyocyte apoptosis by using curcumin nanoparticles. Colloids Surf. B Biointerfaces 2017, 153, 174-182. [CrossRef]

157. Spyratou, E.; Makropoulou, M.; Efstathopoulos, E.; Georgakilas, A.; Sihver, L. Recent Advances in Cancer Therapy Based on Dual Mode Gold Nanoparticles. Cancers 2017, 9, 173. [CrossRef]

158. Li, J.; Gupta, S.; Li, C. Research perspectives: Gold nanoparticles in cancer theranostics. Quant. Imaging Med. Surg. 2013, 3, 284-291.

159. Herold, I.J.D.D.M. Gold microspheres: A selective technique for producing biologically effective dose enhancement. Int. J. Radiat. Biol. 2000, 76, 1357-1364. [CrossRef]

160. Hainfeld, J.F.; Smilowitz, H.M.; O'Connor, M.J.; Dilmanian, F.A.; Slatkin, D.N. Gold nanoparticle imaging and radiotherapy of brain tumors in mice. Nanomedicine 2013, 8, 1601-1609. [CrossRef]

161. Chang, M.-Y.; Shiau, A.-L.; Chen, Y.-H.; Chang, C.-J.; Chen, H.H.W.; Wu, C.-L. Increased apoptotic potential and dose-enhancing effect of gold nanoparticles in combination with single-dose clinical electron beams on tumor-bearing mice. Cancer Sci. 2008, 99, 1479-1484. [CrossRef] [PubMed]

162. Liu, C.-J.; Wang, C.-H.; Chen, S.-T.; Chen, H.-H.; Leng, W.-H.; Chien, C.-C.; Wang, C.-L.; Kempson, I.M.; Hwu, Y.; Lai, T.-C.; et al. Enhancement of cell radiation sensitivity by pegylated gold nanoparticles. Phys. Med. Biol. 2010, 55, 931-945. [CrossRef] [PubMed]

163. Nakamura, T.; Tamura, A.; Murotani, H.; Oishi, M.; Jinji, Y.; Matsuishi, K.; Nagasaki, Y. Large payloads of gold nanoparticles into the polyamine network core of stimuli-responsive PEGylated nanogels for selective and noninvasive cancer photothermal therapy. Nanoscale 2010, 2, 739-746. [CrossRef] [PubMed]

164. Oishi, M.; Nagasaki, Y. Synthesis, characterization, and biomedical applications of core-shell-type stimuli-responsive nanogels-Nanogel composed of poly[2-( $N, N$-diethylamino)ethyl methacrylate] core and PEG tethered chains. React. Funct. Polym. 2007, 67, 1311-1329. [CrossRef]

165. Pan, Y.; Leifert, A.; Ruau, D.; Neuss, S.; Bornemann, J.; Schmid, G.; Brandau, W.; Simon, U.; Jahnen-Dechent, W. Gold Nanoparticles of Diameter $1.4 \mathrm{~nm}$ Trigger Necrosis by Oxidative Stress and Mitochondrial Damage. Small 2009, 5, 2067-2076. [CrossRef] [PubMed]

166. Wang, J.; Fang, X.; Liang, W. Pegylated Phospholipid Micelles Induce Endoplasmic Reticulum-Dependent Apoptosis of Cancer Cells but not Normal Cells. ACS Nano 2012, 6, 5018-5030. [CrossRef]

167. Zhou, J.; Yang, F.; Zhou, Q.; Yang, K.; Chen, W. Magnetic resonance imaging tracking of ultra small superparamagnetic iron oxide labeled rabbit dendritic cells. Exp. Biol. Med. 2013, 239, 13-23. [CrossRef] [PubMed]

168. Smits, L.P.; Coolen, B.F.; Panno, M.D.; Runge, J.H.; Nijhof, W.H.; Verheij, J.; Nieuwdorp, M.; Stoker, J.; Beuers, U.H.; Nederveen, A.J.; et al. Noninvasive Differentiation between Hepatic Steatosis and Steatohepatitis with MR Imaging Enhanced with USPIOs in Patients with Nonalcoholic Fatty Liver Disease: A Proof-of-Concept Study. Radiology 2016, 278, 782-791. [CrossRef]

169. Kanematsu, M.; Kondo, H.; Goshima, S.; Kato, H.; Tsuge, U.; Hirose, Y.; Kim, M.-J.; Moriyama, N. Imaging Liver Metastases: Review and Update. Eur. J. Radiol. 2006, 58, 217-228. [CrossRef]

170. Tanimoto, A.; Kuribayashi, S. Application of Superparamagnetic Iron Oxide to Imaging of Hepatocellular Carcinoma. Eur. J. Radiol. 2006, 58, 200-216. [CrossRef]

171. Rock, K.L.; Kono, H. The Inflammatory Response to Cell Death. Annu. Rev. Pathol. Mech. Dis. 2008, 3, 99-126. [CrossRef] [PubMed]

172. He, C.; Jiang, S.; Yao, H.; Zhang, L.; Yang, C.; Zhan, D.; Lin, G.; Zeng, Y.; Xia, Y.; Lin, Z.; et al. Endoplasmic reticulum stress mediates inflammatory response triggered by ultra-small superparamagnetic iron oxide nanoparticles in hepatocytes. Nanotoxicology 2018, 12, 1198-1214. [CrossRef] [PubMed]

173. Sangaiya, P.; Jayaprakash, R. A Review on Iron Oxide Nanoparticles and Their Biomedical Applications. J. Supercond. Nov. Magn. 2018, 31, 3397-3413. [CrossRef]

174. Rajendran, K.; Karunagaran, V.; Mahanty, B.; Sen, S. Biosynthesis of hematite nanoparticles and its cytotoxic effect on HepG2 cancer cells. Int. J. Biol. Macromol. 2015, 74, 376-381. [CrossRef]

175. Calero, M.; Chiappi, M.; Lazaro-Carrillo, A.; Rodriguez, M.J.; Chichon, F.J.; Crosbie-Staunton, K.; Prina-Mello, A.; Volkov, Y.; Villanueva, A.; Carrascosa, J.L. Characterization of interaction of magnetic nanoparticles with breast cancer cells. J. Nanobiotechnol. 2015, 13, 1-15. [CrossRef] 
176. Abrams, D.B.; Witkiewitz, K.; Fulmer, T.; Tanenbaum, M.L.; Commissariat, P.; Kupperman, E.; Baek, R.N.; Gonzalez, J.S.; Heaney, J.; Kline, C.; et al. Apple Shaped. Encycl. Behav. Med. 2013, 281, 124. [CrossRef]

177. Kossatz, S.; Grandke, J.; Couleaud, P.; Latorre, A.; Aires, A.; Crosbie-Staunton, K.; Ludwig, R.; Dahring, H.; Ettelt, V.; Lazaro-Carrillo, A.; et al. Efficient treatment of breast cancer xenografts with multifunctionalized iron oxide nanoparticles combining magnetic hyperthermia and anti-cancer drug delivery. Breast Cancer Res. 2015, 17, 1-17. [CrossRef]

178. Nagamuthu, S.; Vijayakumar, S.; Muralidharan, G. Synthesis of $\mathrm{Mn}_{3} \mathrm{O}_{4} /$ Amorphous Carbon Nanoparticles as Electrode Material for High Performance Supercapacitor Applications. Energy Fuels 2013, 27, 3508. [CrossRef]

179. Parveen, A.; Rizvi, S.H.M.; Tiwari, S.; Mahdi, A.A. Manganese Nanoparticles Induce Endoplasmic Reticulum Stress Mediated Cell Death in Primary Hippocampal Neuron Culture. Free Radic. Biol. Med. 2017, 112, 77. [CrossRef]

180. Pradhan, S.; Patra, P.; Das, S.; Chandra, S.; Mitra, S.; Dey, K.K.; Akbar, S.; Palit, P.; Goswami, A. Photochemical Modulation of Biosafe Manganese Nanoparticles on Vigna radiata: A Detailed Molecular, Biochemical, and Biophysical Study. Environ. Sci. Technol. 2013, 47, 13122-13131. [CrossRef] [PubMed]

181. Sanfins, E.; Dairou, J.; Rodrigues-Lima, F.; Dupret, J.-M. Nanoparticle-protein interactions: From crucial plasma proteins to key enzymes. J. Phys. Conf. Ser. 2011, 304, 012039. [CrossRef]

182. Marano, S.; Hussain, F.; Rodrigues-Lima, A.; Baeza-Squiban, A.; Boland, S. Nanoparticles: Molecular targets and cell signalling. Arch. Toxicol. 2011, 85, 733. [CrossRef] [PubMed]

183. Alarifi, S.; Ali, D.; Alkahtani, S. Oxidative Stress-Induced DNA Damage by Manganese Dioxide Nanoparticles in Human Neuronal Cells. BioMed Res. Int. 2017, 2017, 5478790. [CrossRef] [PubMed]

184. Yi, X.; Zhao, W.; Li, J.; Zhang, B.; Yu, Q.; Li, M. Mn3O4nanoparticles cause endoplasmic reticulum stress-dependent toxicity to Saccharomyces cerevisiae. RSC Adv. 2017, 7, 46028-46035. [CrossRef]

185. Li, J.; Wang, X.; Jiang, H.; Lü, X.; Zhu, Y.; Chen, B. New strategy of photodynamic treatment of $\mathrm{TiO}_{2}$ nanofibers combined with celastrol for HepG2 proliferation in vitro. Nanoscale 2011, 3, 3115-3122. [CrossRef]

186. Reeves, J.F.; Davies, S.J.; Dodd, N.J.; Jha, A.N. Hydroxyl radicals $(\mathrm{OH})$ are associated with titanium dioxide $\left(\mathrm{TiO}_{2}\right)$ nanoparticle-induced cytotoxicity and oxidative DNA damage in fish cells. Mutat. Res. 2008, 640, 113-122. [CrossRef]

187. Tang, Y.; Wang, F.; Jin, C.; Liang, H.; Zhong, X.; Yang, Y. Mitochondrial injury induced by nanosized titanium dioxide in A549 cells and rats. Environ. Toxicol. Pharmacol. 2013, 36, 66-72. [CrossRef]

188. Oesch, F.; Landsiedel, R. Genotoxicity investigations on nanomaterials. Arch. Toxicol. 2012, 86, 985-994. [CrossRef]

189. Van Vliet, A.R.; Verfaillie, T.; Agostinis, P. New functions of mitochondria associated membranes in cellular signaling. Biochim. Biophys. Acta (BBA) Mol. Cell Res. 2014, 1843, 2253-2262. [CrossRef]

190. Verma, S.K.; Jha, E.; Panda, P.K.; Thirumurugan, A.; Parashar, S.K.S.; Patro, S.; Suar, M. Mechanistic Insight into Size-Dependent Enhanced Cytotoxicity of Industrial Antibacterial Titanium Oxide Nanoparticles on Colon Cells Because of Reactive Oxygen Species Quenching and Neutral Lipid Alteration. ACS Omega 2018, 3, 1244-1262. [CrossRef]

191. Shukla, R.K.; Sharma, V.; Pandey, A.K.; Singh, S.; Sultana, S.; Dhawan, A. ROS-mediated genotoxicity induced by titanium dioxide nanoparticles in human epidermal cells. Toxicol. In Vitro 2011, 25, 231-241. [CrossRef]

192. Aliakbari, F.; Hosseinali, S.H.; Sarokhalil, Z.K.; Shahpasand, K.; Saboury, A.A.; Akhtari, K.; Falahati, M. Reactive oxygen species generated by titanium oxide nanoparticles stimulate the hemoglobin denaturation and cytotoxicity against human lymphocyte cell. J. Biomol. Struct. Dyn. 2019, 37, 4875-4881. [CrossRef] [PubMed]

193. Malhotra, J.D.; Kaufman, R.J. ER Stress and Its Functional Link to Mitochondria: Role in Cell Survival and Death. Cold Spring Harb. Perspect. Biol. 2011, 3, a004424. [CrossRef] [PubMed]

194. Yu, K.-N.; Yoon, T.-J.; Minai-Tehrani, A.; Kim, J.-E.; Park, S.J.; Jeong, M.S.; Ha, S.-W.; Lee, J.-K.; Kim, J.S.; Cho, M.-H. Zinc oxide nanoparticle induced autophagic cell death and mitochondrial damage via reactive oxygen species generation. Toxicol. In Vitro 2013, 27, 1187-1195. [CrossRef] [PubMed]

195. Murdock, R.C.; Braydich-Stolle, L.; Schrand, A.M.; Schlager, J.J.; Hussain, S.M. Characterization of nanomaterial dispersion in solution prior to in vitro exposure using dynamic light scattering technique. Toxicol. Sci. 2008, 10, 239-253. [CrossRef] [PubMed]

196. Kahn, B.B.; Alquier, T.; Carling, D.; Hardie, D.G. AMP-activated protein kinase: Ancient energy gauge provides clues to modern understanding of metabolism. Cell Metab. 2005, 1, 15-25. [CrossRef] [PubMed] 
197. Chen, R.; Huo, L.; Shi, X.; Bai, R.; Zhang, Z.; Zhao, Y.; Chang, Y.; Chen, C. Endoplasmic Reticulum Stress Induced by Zinc Oxide Nanoparticles Is an Earlier Biomarker for Nanotoxicological Evaluation. ACS Nano 2014, 8, 2562-2574. [CrossRef]

198. Piccinno, F.; Gottschalk, F.; Seeger, S.; Nowack, B. Industrial production quantities and uses of ten engineered nanomaterials in Europe and the world. J. Nanoparticle Res. 2012, 14, 1-11. [CrossRef]

199. Cyphert, J.M.; Hargrove, M.M.; Nyska, A.; Schladweiler, M.C.; Kodavanti, U.P.; Gavett, S.H. Long-term toxicity of naturally occurring asbestos in male Fischer 344 rats. J. Toxicol. Environ. Health Part A 2016, 79, 49-60. [CrossRef]

200. Pastero, L.; Turci, F.; Leinardi, R.; Pavan, C.; Monopoli, M. Synthesis of $\alpha$-Quartz with Controlled Properties for the Investigation of the Molecular Determinants in Silica Toxicology. Cryst. Growth Des. 2016, 16, 2394-2403. [CrossRef]

201. Turci, F.; Pavan, C.; Leinardi, R.; Tomatis, M.; Pastero, L.; Garry, D.; Anguissola, S.; Lison, D.; Fubini, B. Revisiting the paradigm of silica pathogenicity with synthetic quartz crystals: The role of crystallinity and surface disorder. Part. Fibre Toxicol. 2015, 13, 1-12. [CrossRef] [PubMed]

202. Kawasaki, H. A mechanistic review of silica-induced inhalation toxicity. Inhal. Toxicol. 2015, 27, 363-377. [CrossRef] [PubMed]

203. Echaudhari, N.; Etalwar, P.; Eparimisetty, A.; d'Hellencourt, C.L.; Ravanan, P. A Molecular Web: Endoplasmic Reticulum Stress, Inflammation, and Oxidative Stress. Front. Cell. Neurosci. 2014, 8, 213. [CrossRef]

204. Valavanidis, A.; Vlachogianni, T.; Fiotakis, K.; Loridas, S. Pulmonary Oxidative Stress, Inflammation and Cancer: Respirable Particulate Matter, Fibrous Dusts and Ozone as Major Causes of Lung Carcinogenesis through Reactive Oxygen Species Mechanisms. Int. J. Environ. Res. Public Health 2013, 10, 3886-3907. [CrossRef] [PubMed]

205. Sushma, S.; Kumar, H.; Ahmad, I.; Dutta, P.K. Evaluation of the DNA damaging potential of indigenous health hazardous quartz nanoparticles on the cultured lung cells. Toxicol. Res. 2017, 6, 152-161. [CrossRef] [PubMed]

206. Kaufman, R.J.; Malhotra, J.D. Calcium trafficking integrates endoplasmic reticulum function with mitochondrial bioenergetics. Biochim. Biophys. Acta (BBA) Mol. Cell Res. 2014, 1843, 2233-2239. [CrossRef]

207. Kania, E.; Pająk, B.; Orzechowski, A. Calcium Homeostasis and ER Stress in Control of Autophagy in Cancer Cells. BioMed Res. Int. 2015, 2015, 1-12. [CrossRef]

208. Rizzuto, R.; De Stefani, D.; Raffaello, A.; Mammucari, C. Mitochondria as sensors and regulators of calcium signalling. Nat. Rev. Mol. Cell Biol. 2012, 13, 566-578. [CrossRef]

209. Orrenius, S.; Gogvadze, V.; Zhivotovsky, B. Calcium and mitochondria in the regulation of cell death. Biochem. Biophys. Res. Commun. 2015, 460, 72-81. [CrossRef]

210. Mittal, S.; Pandey, A.K. Cerium Oxide Nanoparticles Induced Toxicity in Human Lung Cells: Role of ROS Mediated DNA Damage and Apoptosis. BioMed Res. Int. 2014, 2014, 1-14. [CrossRef]

211. Akhtar, M.J.; Ahamed, M.; Khan, M.A.; Alrokayan, S.A.; Ahmad, I.; Kumar, S. Cytotoxicity and apoptosis induction by nanoscale talc particles from two different geographical regions in human lung epithelial cells? Environ. Toxicol. 2014, 29, 394-406. [CrossRef] [PubMed]

212. Passagne, I.; Morille, M.; Rousset, M.; Pujalté, I.; L'Azou, B. Implication of oxidative stress in size-dependent toxicity of silica nanoparticles in kidney cells. Toxicology 2012, 299, 112-124. [CrossRef] [PubMed]

213. Napierska, D.; Thomassen, L.C.; Lison, D.; Martens, J.A.; Hoet, P.H.M. The nanosilica hazard: Another variable entity. Part. Fibre Toxicol. 2010, 7, 39. [CrossRef] [PubMed]

214. Ariano, P.; Zamburlin, A.; Gilardino, R.; Mortera, B.; Onida, M.; Tomatis, M.; Ghiazza, B.; Fubini, D.; Lovisolo, D. Interaction of spherical silica nanoparticleswith neuronal cells: Size dependent toxicity and perturbation of calciumhomeostasis. Small 2011, 7, 766-774. [CrossRef] [PubMed]

215. Tarantini, R.; Lanceleur, A.; Mourot, M.T.; Lavault, G.; Casterou, G.; Jarry, K.; Hogeveen, V.; Fessard, V. Toxicity, genotoxicity and proinflammatory effects ofamorphous nanosilica in the human intestinal Caco-2 cell line. Toxicol. In Vitro 2015, 29, 398-407. [CrossRef] [PubMed]

216. Sahu, D.; Vijayaraghavan, R.; Kannan, G.M. Silica nanoparticle induces oxidativestress and provokes inflammation in human lung cells, Experiment. Nanoscience 2015, 10, 983-1000.

217. Panas, C.; Marquardt, O.; Nalcaci, H.; Bockhorn, W.; Baumann, H.R.; Paur, S.; Mülhopt, S.; Diabaté, C.; Weiss, C. Screening of different metal oxide nanoparticlesreveals selective toxicity and inflammatory potential of silica nanoparticles inlung epithelial cells and macrophages. Nanotoxicology 2013, 7, 259-273. [CrossRef] 
218. Christen, V.; Fent, K. Silica nanoparticles and silver-doped silica nanoparticles induce endoplasmic reticulum stress response and alter cytochromeP4501A activity. Chemosphere 2012, 87, 423-434. [CrossRef]

219. Christen, V.; Camenzind, M.; Fent, K. Silica nanoparticles induce endoplasmic reticulum stress response, oxidative stress and activate the mitogen-activated protein kinase (MAPK) signaling pathway. Toxicol. Rep. 2014, 1, 1143-1151. [CrossRef]

220. Hu, H.; Fan, X.; Guo, Q.; Wei, X.; Yang, D.; Zhang, B.; Liu, J.; Wu, Q.; Oh, Y.; Feng, Y.; et al. Silicon dioxide nanoparticles induce insulin resistance through endoplasmic reticulum stress and generation of reactive oxygen species. Part. Fibre Toxicol. 2019, 16, 1-18. [CrossRef]

221. Ghosh, C.; Nandi, A.; Basu, S. Lipid Nanoparticle-Mediated Induction of Endoplasmic Reticulum Stress in Cancer Cells. ACS Appl. Bio Mater. 2019, 2, 3992-4001. [CrossRef]

222. Ghalhar, M.G.; Akbarzadeh, A.; Rahmati, M.; Mellatyar, H.; Dariushnejad, H.; Zarghami, N.; Barkhordari, A. Comparison of inhibitory effects of 17-AAG nanoparticles and free 17-AAG on HSP90 gene expression in breast cancer. Asian Pac. J. Cancer Prev. 2014, 15, 7113-7118. [CrossRef] [PubMed]

223. Jiang, D.; Lynch, C.; Medeiros, B.C.; Liedtke, M.; Bam, R.; Tam, A.B.; Yang, Z.; Alagappan, M.; Abidi, P.; Le, Q.T.; et al. Identification of doxorubicin as an inhibitor of the ire $1 \alpha$-xbp1 axis of the unfolded protein response. Sci. Rep. 2016, 6, 33353. [CrossRef] [PubMed]

224. Xu, Y.; Wang, C.; Li, Z. A new strategy of promoting cisplatin chemotherapeutic efficiency by targeting endoplasmic reticulum stress. Mol. Clin. Oncol. 2014, 2, 3-7. [CrossRef]

225. Karasawal, T.; Sibrian-Vazquez, M.; Strongin, R.M.; Steyger, P.S. Identification of cisplatin-binding proteins using agarose conjugates of platinum compounds. PLoS ONE 2013, 8, e66220.

226. Chen, G.-Y.; Yang, H.-J.; Lu, C.-H.; Chao, Y.-C.; Hwang, S.-M.; Chen, C.-L.; Lo, K.-W.; Sung, L.-Y.; Luo, W.-Y.; Tuan, H.-Y.; et al. Simultaneous induction of autophagy and toll-like receptor signaling pathways by graphene oxide. Biomaterials 2012, 33, 6559-6569. [CrossRef]

227. Jin, P.; Wei, P.; Zhang, Y.; Lin, J.; Sha, R.; Hu, Y.; Zhang, J.; Zhou, W.; Yao, H.; Ren, L.; et al. Autophagy-mediated clearance of ubiquitinated mutant huntingtin by graphene oxide. Nanoscale 2016, 8, 18740-18750. [CrossRef]

228. Pandey, S.; Nandi, A.; Basu, S.; Ballav, N. Inducing endoplasmic reticulum stress in cancer cells by graphene oxide-based nanoparticles. Nanoscale Adv. 2020. [CrossRef]

229. Wang, J.; Song, Y.; Zhang, M.; Wu, Z.; Xu, Y.-J.; Lin, J.; Ling, D.; Sheng, Y.; Lu, Y.; Wu, Q.; et al. A liposomal curcumol nanocomposite for magnetic resonance imaging and endoplasmic reticulum stress-mediated chemotherapy of human primary ovarian cancer. J. Mater. Chem. B 2019, 7, 2938-2947. [CrossRef]

230. Song, Y.; Sheng, Z.; Xu, Y.; Dong, L.; Xu, W.; Li, F.; Wang, J.; Wu, Z.; Yang, Y.; Su, Y.; et al. Magnetic liposomal emodin composite with enhanced killing efficiency against breast cancer. Biomater. Sci. 2019, 7, 867-875. [CrossRef]

231. Mollereau, B. Establishing Links between Endoplasmic Reticulum-Mediated Hormesis and Cancer. Mol. Cell. Biol. 2013, 33, 2372-2374. [CrossRef] [PubMed]

232. Foufelle, F.; Fromenty, B. Role of endoplasmic reticulum stress in drug-induced toxicity. Pharmacol. Res. Perspect. 2016, 4, e00211. [CrossRef] [PubMed]

233. He, H.; Xu, B. Instructed-assembly (IA): A molecular process for controlling cell fate. Bull. Chem. Soc. Jpn. 2018, 91, 900. [CrossRef] [PubMed]

234. Feng, Z.Q.Q.; Wang, H.M.; Du, X.W.; Shi, J.F.; Li, J.; Xu, B. Minimal C-terminal modification boosts peptide self-assembling ability for necroptosis of cancer cells. Chem. Commun. 2016, 52, 6332-6335. [CrossRef]

235. Tanaka, A.; Fukuoka, Y.; Morimoto, Y.; Honjo, T.; Koda, D.; Goto, M.; Maruyama, T.J. Cancer cell death induced by the intracellular self-assembly of an enzyme-responsive supramolecular gelator. Am. Chem. Soc. 2015, 137, 770. [CrossRef]

236. Kholodenko, B.N.; Hoek, J.B.; Westerhoff, H.V. Why cytoplasmic signalling proteins should be recruited to cell membranes. Trends Cell Biol. 2000, 10, 173. [CrossRef]

237. Cai, Y.; Shen, H.; Zhan, J.; Lin, M.; Dai, L.; Ren, C.; Shi, Y.; Liu, J.; Gao, J.; Yang, Z. Supramolecular "Trojan Horse" for nuclear delivery of dual anticancer drugs. J. Am. Chem. Soc. 2017, 139, 2876. [CrossRef]

238. Wang, H.; Feng, Z.; Wang, Y.; Zhou, R.; Yang, Z.; Xu, B.J. Integrating enzymatic self-assembly and mitochondria targeting for selectively killing cancer cells without acquired drug resistance. Am. Chem. Soc. 2016, 138, 16046. [CrossRef]

239. Abu Gazia, M.; El-Magd, M.A. Effect of pristine and functionalized multiwalled carbon nanotubes on rat renal cortex. Acta Histochem. 2018, 121, 207-217. [CrossRef] 
240. Guo, Y.-Y.; Zhang, J.; Zheng, Y.-F.; Yang, J.; Zhu, X.-Q. Cytotoxic and genotoxic effects of multi-wall carbon nanotubes on human umbilical vein endothelial cells in vitro. Mutat. Res. Toxicol. Environ. Mutagen. 2011, 721, 184-191. [CrossRef]

241. Orecna, M.; De Paoli, S.H.; Janouskova, O.; Tegegn, T.Z.; Filipova, M.; Bonevich, J.E.; Holada, K.; Simak, J. Toxicity of carboxylated carbon nanotubes in endothelial cells is attenuated by stimulation of the autophagic flux with the release of nanomaterial in autophagic vesicles. Nanomed. Nanotechnol. Biol. Med. 2014, 10, e939-e948. [CrossRef] [PubMed]

242. Zhao, X.; Chang, S.; Long, J.; Li, J.; Li, X.; Cao, Y. The toxicity of multi-walled carbon nanotubes (MWCNTs) to human endothelial cells: The influence of diameters of MWCNTs. Food Chem. Toxicol. 2019, 126, 169-177. [CrossRef]

243. Saleem, J.; Wang, L.; Chen, C. Carbon-Based Nanomaterials for Cancer Therapy via Targeting Tumor Microenvironment. Adv. Health Mater. 2018, 7, e1800525. [CrossRef] [PubMed]

244. Zhang, X.; Shen, W.; Gurunathan, S. Silver Nanoparticle-Mediated Cellular Responses in Various Cell Lines: An in Vitro Model. Int. J. Mol. Sci. 2016, 17, 1603. [CrossRef] [PubMed]

245. Faedmaleki, F.; Shirazi, F.H.; Salarian, A.-A.; Ashtiani, H.A.; Rastegar, H. Toxicity Effect of Silver Nanoparticles on Mice Liver Primary Cell Culture and HepG2 Cell Line. Iran. J. Pharm. Res. IJPR 2014, 13, 235-242.

246. Akter, M.; Sikder, T.; Rahman, M.; Ullah, A.A.; Hossain, K.F.B.; Banik, S.; Hosokawa, T.; Saito, T.; Kurasaki, M. A systematic review on silver nanoparticles-induced cytotoxicity: Physicochemical properties and perspectives. J. Adv. Res. 2018, 9, 1-16. [CrossRef]

247. Bin-Jumah, M.; Al-Abdan, M.; Albasher, G.; Alarifi, S. Effects of Green Silver Nanoparticles on Apoptosis and Oxidative Stress in Normal and Cancerous Human Hepatic Cells in vitro. Int. J. Nanomed. 2020, 15, 1537-1548. [CrossRef]

248. Hekmat, A.; Saboury, A.A.; Divsalar, A. The Effects of Silver Nanoparticles and Doxorubicin Combination on DNA Structure and Its Antiproliferative Effect Against T47D and MCF7 Cell Lines. J. Biomed. Nanotechnol. 2012, 8, 968-982. [CrossRef]

249. Gunduz, N.; Ceylan, H.; Guler, M.O.; Tekinay, A.B. Intracellular Accumulation of Gold Nanoparticles Leads to Inhibition of Macropinocytosis to Reduce the Endoplasmic Reticulum Stress. Sci. Rep. 2017, 7, 1-10. [CrossRef]

250. Rahme, K.; Minassian, G.B.; Sarkis, M.; Nakhl, M.; El Hage, R.; Souaid, E.; Holmes, J.D.; Ghanem, E. Assessment of Charged AuNPs: From Synthesis to Innate Immune Recognition. J. Nanomater. 2018, 2018, 1-12. [CrossRef]

251. Huai, Y.; Zhang, Y.; Xiong, X.; Das, S.; Bhattacharya, R.; Mukherjee, P. Gold Nanoparticles sensitize pancreatic cancer cells to gemcitabine. Cell Stress 2019, 3, 267-279. [CrossRef] [PubMed]

252. Huang, Y.-C.; Yang, Y.-C.; Yang, K.-C.; Shieh, H.-R.; Wang, T.-Y.; Hwu, Y.; Chen, Y.-J. Pegylated Gold Nanoparticles Induce Apoptosis in Human Chronic Myeloid Leukemia Cells. BioMed Res. Int. 2014, 2014, 1-9. [CrossRef] [PubMed]

253. Yasui, H.; Takeuchi, R.; Nagane, M.; Meike, S.; Nakamura, Y.; Yamamori, T.; Ikenaka, Y.; Kon, Y.; Murotani, H.; Oishi, M.; et al. Radiosensitization of tumor cells through endoplasmic reticulum stress induced by PEGylated nanogel containing gold nanoparticles. Cancer Lett. 2014, 347, 151-158. [CrossRef] [PubMed]

254. Shen, J.; Yang, D.; Zhou, X.; Wang, Y.; Tang, S.; Yin, H.; Wang, J.; Chen, R.; Chen, J. Role of Autophagy in Zinc Oxide Nanoparticles-Induced Apoptosis of Mouse LEYDIG Cells. Int. J. Mol. Sci. 2019, 20, 4042. [CrossRef] [PubMed]

255. Ng, C.T.; Yong, L.Q.; Hande, M.P.; Ong, C.N.; Yu, L.E.; Bay, B.H.; Baeg, G.H. Zinc oxide nanoparticles exhibit cytotoxicity and genotoxicity through oxidative stress responses in human lung fibroblasts and Drosophila melanogaster. Int. J. Nanomed. 2017, 12, 1621-1637. [CrossRef] [PubMed]

256. An, S.S.A.; Kim, Y.-R.; Park, J.-I.; Lee, E.J.; Park, S.H.; Seong, N.-W.; Kim, J.-H.; Kim, G.-Y.; Meang, E.-H.; Hong, J.-S.; et al. Toxicity of $100 \mathrm{~nm}$ zinc oxide nanoparticles: A report of 90-day repeated oral administration in Sprague Dawley rats. Int. J. Nanomed. 2014, 9, 109-126. [CrossRef] [PubMed]

257. Bose, K.; Lakshminarasimhan, H.; Sundar, K.; Kathiresan, T. Cytotoxic effect of ZnS nanoparticles on primary mouse retinal pigment epithelial cells. Artif. Cells Nanomed. Biotechnol. 2015, 44, 1764-1773. [CrossRef]

258. Mirshafiee, V.; Sun, B.; Chang, C.H.; Liao, Y.-P.; Jiang, W.; Jiang, J.; Liu, X.; Wang, X.; Xia, T.; Nel, A.E. Toxicological Profiling of Metal Oxide Nanoparticles in Liver Context Reveals Pyroptosis in Kupffer Cells and Macrophages versus Apoptosis in Hepatocytes. ACS Nano 2018, 12, 3836-3852. [CrossRef] 
259. Hamzian, N.; Hashemi, M.; Ghorbani, M.; Toosi, M.H.B.; Ramezani, M. Preparation, Optimization and Toxicity Evaluation of (SPION-PLGA) \pm PEG Nanoparticles Loaded with Gemcitabine as a Multifunctional Nanoparticle for Therapeutic and Diagnostic Applications. Iran. J. Pharm. Res. IJPR 2017, 16, 8-21.

260. Rueda-Romero, C.; Hernández-Pérez, G.; Ramos-Godínez, P.; Vázquez-López, I.; Quintana-Belmares, R.O.; Huerta-García, E.; Stępień, E.; López-Marure, R.; Montiel-Dávalos, A.; Alfaro-Moreno, E. Titanium dioxide nanoparticles induce the expression of early and late receptors for adhesion molecules on monocytes. Part. Fibre Toxicol. 2015, 13, 1-13. [CrossRef]

261. Binet, S.; Canu, I.G.; Emond, C.; Fessard, V.; Flahaut, E.; Schroeder, H.; Salles, B.; Sorg, O.; Sparfel, L.; Vasseur, P. Le dioxyde de titane sous forme nanoparticulaire. Valeurs toxicologiques de référence. Le dioxyde de titane sous forme nanoparticulaire. Valeurs toxicologiques de référence. Avis de l'Anses. Collective expert appraisal report. ANSES 2019, 1, 1-120.

262. Tada-Oikawa, S.; Ichihara, G.; Fukatsu, H.; Shimanuki, Y.; Tanaka, N.; Watanabe, E.; Suzuki, Y.; Murakami, M.; Izuoka, K.; Chang, J.; et al. Titanium Dioxide Particle Type and Concentration Influence the Inflammatory Response in Caco-2 Cells. Int. J. Mol. Sci. 2016, 17, 576. [CrossRef] [PubMed]

263. Yan, M.; Zhang, Y.; Qin, H.; Liu, K.; Guo, M.; Ge, Y.; Xu, M.; Sun, Y.; Zheng, X. Cytotoxicity of CdTe quantum dots in human umbilical vein endothelial cells: The involvement of cellular uptake and induction of pro-apoptotic endoplasmic reticulum stress. Int. J. Nanomed. 2016, 11, 529-542. [CrossRef] [PubMed]

264. Hou, C.-C.; Tsai, T.-L.; Su, W.-P.; Hsieh, H.-P.; Yeh, C.-S.; Shieh, D.-B.; Su, W.-C. Pronounced induction of endoplasmic reticulum stress and tumor suppression by surfactant-free poly(lactic-co-glycolic acid) nanoparticles via modulation of the PI3K signaling pathway. Int. J. Nanomed. 2013, 8, 2689-2707. [CrossRef] [PubMed]

265. Niu, J.; Azfer, A.; Rogers, L.M.; Wang, X.; Kolattukudy, P.E. Cardioprotective effects of cerium oxide nanoparticles in a transgenic murine model of cardiomyopathy. Cardiovasc. Res. 2007, 73, 549-559. [CrossRef]

266. Tapeinos, C.; Battaglini, M.; Prato, M.; La Rosa, G.; Scarpellini, A.; Ciofani, G. CeO2 Nanoparticles-Loaded $\mathrm{pH}$-Responsive Microparticles with Antitumoral Properties as Therapeutic Modulators for Osteosarcoma. ACS Omega 2018, 3, 8952-8962. [CrossRef]

267. Yan, M.; Zhang, Z.; Cui, S.; Lei, M.; Zeng, K.; Liao, Y.; Chu, W.; Deng, Y.; Zhao, C. Improvement of pharmacokinetic and antitumor activity of layered double hydroxide nanoparticles by coating with PEGylated phospholipid membrane. Int. J. Nanomed. 2014, 9, 4867.

268. Meng, J.; Liang, X.; Chen, X.; Zhao, Y. Biological characterizations of $\left[\mathrm{Gd} @ \mathrm{C}_{82}(\mathrm{OH})_{22}\right]_{\mathrm{n}}$ nanoparticles as fullerene derivatives for cancer therapy. Integr. Biol. 2012, 5, 43-47. [CrossRef]

269. Wang, H.; Liu, Z.; Gou, Y.; Qin, Y.; Xu, Y.; Liu, J.; Wu, J.-Z. Apoptosis and necrosis induced by novel realgar quantum dots in human endometrial cancer cells via endoplasmic reticulum stress signaling pathway. Int. J. Nanomed. 2015, 10, 5505-5512. [CrossRef]

270. Wang, Y.; Kaur, G.; Chen, Y.; Santos, A.; Losic, D.; Evdokiou, A. Bioinert Anodic Alumina Nanotubes for Targeting of Endoplasmic Reticulum Stress and Autophagic Signaling: A Combinatorial Nanotube-Based Drug Delivery System for Enhancing Cancer Therapy. ACS Appl. Mater. Interfaces 2015, 7, 27140-27151. [CrossRef]

271. Wang, Y.; Kaur, G.; Zysk, A.; Liapis, V.; Hay, S.; Santos, A.; Losic, D.; Evdokiou, A. Systematic in vitro nanotoxicity study on anodic alumina nanotubes with engineered aspect ratio: Understanding nanotoxicity by a nanomaterial model. Biomaterials 2015, 46, 117-130. [CrossRef]

272. Chen, R.; Ling, D.; Zhao, L.; Wang, S.; Liu, Y.; Bai, R.; Baik, S.; Zhao, Y.; Chen, C.; Hyeon, T. Parallel Comparative Studies on Mouse Toxicity of Oxide Nanoparticle- and Gadolinium-Based T1 MRI Contrast Agents. ACS Nano 2015, 9, 12425-12435. [CrossRef] [PubMed]

273. Chiu, H.-W.; Xia, T.; Lee, Y.-H.; Chen, C.-W.; Tsai, J.-C.; Wang, Y.-J. Cationic polystyrene nanospheres induce autophagic cell death through the induction of endoplasmic reticulum stress. Nanoscale 2015, 7, 736-746. [CrossRef] [PubMed] 
274. Park, M.R.; Gurunathan, S.; Choi, Y.J.; Kwon, D.N.; Han, J.W.; Cho, S.G.; Park, C.; Seo, H.G.; Kim, J.H. Chitosan nanoparticles cause pre-and post-implantation embryo complications in mice. Biol. Reprod. 2013, 88, 1-13. [CrossRef] [PubMed]

275. Nasery, M.M.; Abadi, B.; Poormoghadam, D.; Zarrabi, A.; Keyhanvar, P.; Khanbabaei, H.; Ashrafizadeh, M.; Mohammadinejad, R.; Tavakol, S.; Sethi, G. Curcumin Delivery Mediated by Bio-Based Nanoparticles: A Review. Molecules 2020, 25, 689. [CrossRef] [PubMed]

Publisher's Note: MDPI stays neutral with regard to jurisdictional claims in published maps and institutional affiliations.

(C) 2020 by the authors. Licensee MDPI, Basel, Switzerland. This article is an open access article distributed under the terms and conditions of the Creative Commons Attribution (CC BY) license (http://creativecommons.org/licenses/by/4.0/). 